\title{
スタッドを用いた連続合成桁の中間支点部 における疲労挙動に関する実験的研究
}

\author{
富岡佐和子 ${ }^{1} \cdot$ 谷口 望 $2 \cdot$ 碇山 $\quad$ 晴久 ${ }^{3} \cdot$ 依田 照彦 4 \\ 1学生会員 早稲田大学大学院 理工学研究科 建設工学専攻（₹ 169-8555 東京都新宿区大久保 3-4-1) \\ E-mail: sawasdee@ruri.waseda.jp \\ 2正会員 鉄道総合技術研究所 構造物技術研究部 鋼・複合構造（ $\bar{T} 185-8540$ 東京都国分寺市光町 2-8-38) \\ 3 正会員 (株) 東京鐵骨橋梁 技術本部 技術開発部（广 108-0023 東京都港区芝浦 4-18-32） \\ 4フェロー 早稲田大学教授 創造理工学部 社会環境工学科（₹ 169-8555 東京都新宿区大久保 3-4-1）
}

\begin{abstract}
本研究は, 橋梁の構造形式で連続合成桁を採用する際に検討しなければならない中間支点部において, 負曲 げにより生じる RC 床版のスタッドの挙動を把握することを目的としている. 特に, 現在ではまだ検討事例の少 ない疲労試験を行い, 疲労挙動に着目している. 本研究では, 負曲げが発生する連続合成桁の中間支点部をモ デル化して, 疲労試験および静的載荷試験を行った. 本実験結果より, スタッド基部とコンクリートとの付着, 床版の下鉄筋とコンクリートとの付着, および鋼上フランジとコンクリートとの付着は, 初期疲労レベルでは 切れていないと推察でき, 通常の走行時を想定した場合, 疲労試験後も, テンションスティフニングの効果は 期待できることを確認した.
\end{abstract}

Key Words : continuous composite girder, fatigue, crack, stud dubel, tension stiffening

\section{1. はじめに}

合成桁は昭和 26 年頃より建設され始め, 昭和 30 年 代にはプレストレストコンクリートを用いた連続合成 桁が建設された。 やがて, 経済性を追求し, プレストレ スを用いない連続合成桁も検討され始めた ${ }^{1)}$. しかし， 昭和 50 年頃より道路橋においては, 高度経済成長に伴 う交通量の急増や荷重の増大から，コンクリート床版 の損傷が多発し，コンクリートの剛性を設計に考慮する 合成桁は以降ほとんど建設されなくなった。一方，鉄道 橋においては, 昭和 50 年頃より, 中間支点部のジャッ キ操作によるプレストレスを用いた連続合成桁が建設 され，平成に入った後は，柔ジベル等を用いた断続合 成桁が数橋建設されている. 平成 4 年頃より, ドイツ において検討されてきたテンションスティフニング理 論2),3)を活用したひび割れ制御設計法が，日本でも注目 されるようになり4),5),6)，プレストレストコンクリート を用いた道路橋連続合成桁が千鳥の沢橋等で復活した。 また, 合成床版の開発や非合成用スラブアンカーの疲 労問題などもあり，ひび割れ制御設計法を用いた道路 橋連続合成桁は数多く作られるようになった. 近年, こ れを受けて道路橋における手引きも整備され, テンショ ンスティフニング理論を活用したひび割れ制御法を取 り入れたものが出てきており7), 平成 13 年には日本橋 梁建設協会より「PC 床版を有するプレストレスしない 連続合成 2 主析橋の設計例と解説」 ${ }^{8)}$ が，平成 14 年に
は高速道路技術センターより「PC 床版鋼連続合成 2 主 桁橋の設計・施工マニュアル」9)が出版されている. 鉄 道橋においても, 騒音低減・経済性・耐震性向上の観点 から，連続合成桁を採用寸る事例が多く見られるよう になった ${ }^{10)}$.

連続合成桁は, 単純桁構造と比較して構造上各径間 のスパンを長くでき桁高を抑えられ，また桁を連続化 していることから大規模地震にも有利な構造形式であ る. 中間支点部付近の負曲げモーメントを受ける合成 桁の設計においては, ひび割れ後のコンクリートの応 力分担を考慮し, 設計時に適切にそれを評価すること が重要であるが ${ }^{11)}$, 疲労荷重を受けた試験体での実験 的検討はほとんど行われていない.

そこで, 本研究では, 負曲げが発生する連続合成桁 の中間支点部をモデル化して, 疲労試験および静的載 荷試験を行い, 中間支点部の挙動を把握することを目 的とする. 特に, 合成桁のずれ止めとして頭付きスタッ ドを用いた連続合成桁の, 中間支点部における疲労挙 動について検討する ${ }^{12)}$.

\section{2. 実験概要}

\section{(1) 実験供試体}

供試体は図-1 に示すようにスパン $4 \mathrm{~m}$, 床版幅 $0.8 \mathrm{~m}$, 床版厚 $250 \mathrm{~mm}$ で, 実橋における中間支点部を意識し, 鋼桁の中央部を載荷点とした 3 点曲げの試験体である. 


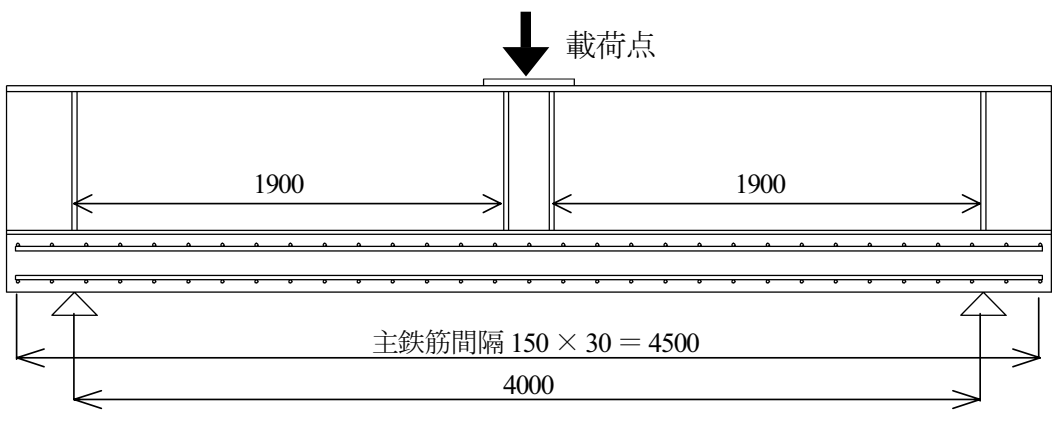

(a) 側面図

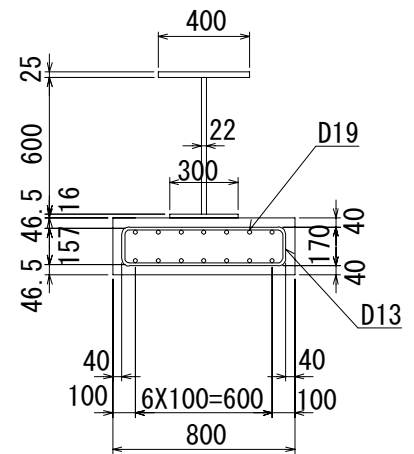

(b) 断面図

図-1 供試体の概要（単位：mm)

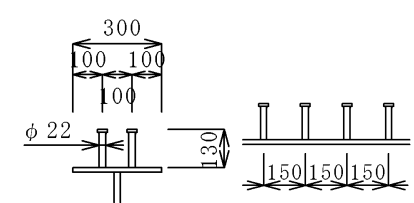

図-2 頭付きスタッド (単位 : mm)

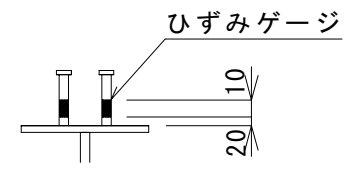

図-3 ひずみゲージ (単位 : mm)

表-1 供試体の種類

\begin{tabular}{c|c|c|c|c}
\hline No. & 供試体名称 & ずれ止め & コンクリート & 疲労試験 \\
\hline $\mathrm{A}$ 体 & 基本 & 頭付きスタッド & 普通 & なし \\
\hline $\mathrm{B}$ 体 & 初期疲労 & 頭付きスタッド & 普通 & $200 \mathrm{kN}, 200$ 万回 \\
\hline $\mathrm{C}$ 体 & 定常疲労 & 頭付きスタッド & 普通 & $600 \mathrm{kN}, 200$ 万回 \\
\hline
\end{tabular}

床版厚と中立軸位置を, 実橋に近い試験体とするため, 床版厚は実橋と同じ $250 \mathrm{~mm}$ とし, 中立軸が鋼桁内に くるよう鋼桁の桁高を抑えたため, ウェブ厚は実橋よ り厚くなっている. 主鉄筋間隔は $150 \mathrm{~mm}$, 鉄筋比 $\rho$ は 2\%とした，スタッドの詳細を図-2 に示す，表-1 に今回 の研究で比較検討を行う 3 体の供試体についてまとめ る. 供試体 A，B，Cではいずれも，普通コンクリート を用い，ずれ止めは頭付きスタッドである．供試体 A は, 疲労試験は行わず静的載荷試験のみを行うもの（以 後, 基本之呼ぶ），供試体 B は，載荷荷重 $200 \mathrm{kN}, 200$ 万回の疲労試験を行い, その後静的載荷試験を行うもの (以後, 初期疲労と呼ぶ), 供試体 C は載荷荷重 $600 \mathrm{kN}$, 200 万回の疲労試験を行い, その後静的載荷試験を行う もの（以後, 定常疲労と呼ぶ）とした.

\section{(2) 実験供試体材料}

\section{a) 鋼桁}

上フランジ・下フランジ・ウェブには SM490 を使用 した. また，各パネル同士は溶接によって接合した。

\section{b) 鉄筋}

軸方向鉄筋（D19），軸直角方向鉄筋（D13）ともに SD345 を使用した.

\section{c) コンクリート}

鋼枌のフランジ上に組み立てた鉄筋を配置し, 型枠 を組んで，実際の構造物と同じように鋼桁を下に，床

表-2 コンクリートの配合条件

\begin{tabular}{c|c|c}
\hline 項目 & 単位 & 普通コンクリート \\
\hline 設計基準強度 & $\mathrm{N} / \mathrm{mm}^{2}$ & 27.0 \\
\hline スランプ & $\mathrm{cm}$ & $8 \pm 2.5$ \\
\hline 空気量 & $\%$ & $4.5 \pm 1.0$ \\
\hline 粗骨材最大寸法 & $\mathrm{mm}$ & 20 \\
\hline 単位セメント量 & $\mathrm{kg} / \mathrm{m}^{3}$ & 230 以上 \\
\hline 水セメント比 & $\%$ & 55 以下 \\
\hline 塩化物含有量 & $\mathrm{kg} / \mathrm{m}^{3}$ & 0.30 以下 \\
\hline
\end{tabular}

表-3 コンクリートの圧縮強度 $\left(\mathrm{N} / \mathrm{mm}^{2}\right)$

\begin{tabular}{l|c|c|c|c}
\hline & 呼び強度 & 7 日強度 & 28 日強度 & \multicolumn{2}{|c}{ 載荷日（材令） } \\
\hline $\mathrm{A}$ (基本) & 27 & 29.7 & 36.0 & 35.1 (47 日) \\
\hline $\mathrm{B}$ (初期疲労) & 27 & 30.6 & 41.2 & $35.8(111$ 日) \\
\hline $\mathrm{C}$ (定常疲労) & 27 & 31.1 & 38.3 & $35.3(103$ 日) \\
\hline
\end{tabular}

版を上にして，コンクリートを打設した。

コンクリートの配合条件, および圧縮強度試験結果 を表-2, 表-3 に示す。

\section{d) スタッド}

スタッドは SS400 を使用し，寸法は図-2 に示したと おりである. 配置量は, 従来の鋼標準 ${ }^{13)}$ の式を用い, 供 試体の耐力を基に設定した.

\section{(3) 実験概要}

\section{a) 疲労試験}

疲労試験では，B 体は $200 \mathrm{kN} ， \mathrm{C}$ 体は $600 \mathrm{kN}$ をそれ ぞれ片振幅で 200 万回載荷した。 疲労載荷周波数は 1.5 〜 $2.5 \mathrm{~Hz}$ である. 計測は疲労載荷前, 載荷回数の合計が 1 万回, 5 万回, 10 万回, 50 万回, 100 万回, 200 万回 載荷ごとに, その疲労荷重を静的載荷することで行う こととし, 疲労試験終了後に終局載荷を行った. B 体の 載荷荷重 $200 \mathrm{kN}$ は, 初期ひび割れが発生する荷重を, $\mathrm{C}$ 体の載荷荷重 $600 \mathrm{kN}$ は, 定常ひび割れが発生する荷 重を想定している.

\section{b) 静的載荷試験}

静的載荷試験では, $180 \mathrm{kN}, 380 \mathrm{kN}, 680 \mathrm{kN}, 1300 \mathrm{kN}$ に到達した時点でいったん $0 \mathrm{kN}$ まで除荷し, その後枌 
CL

$200 \mathrm{kN}$

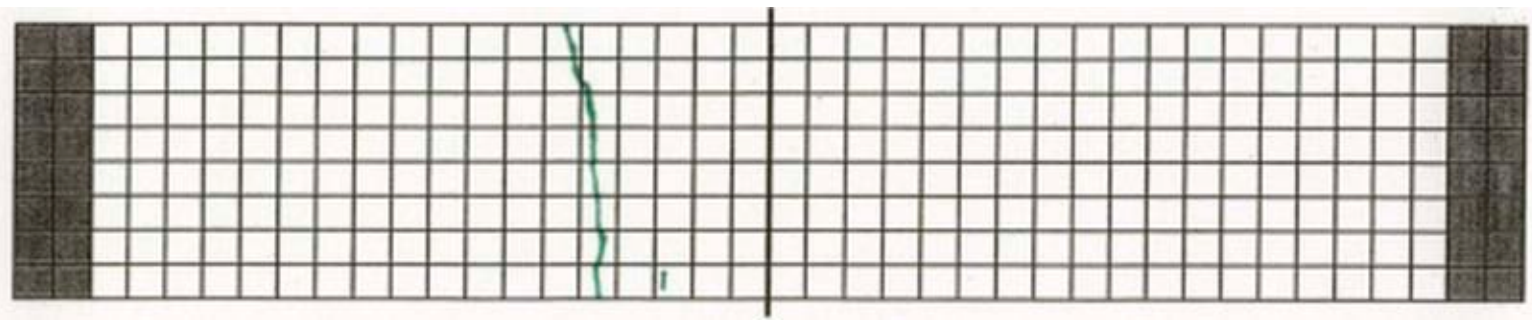

$600 \mathrm{kN}$

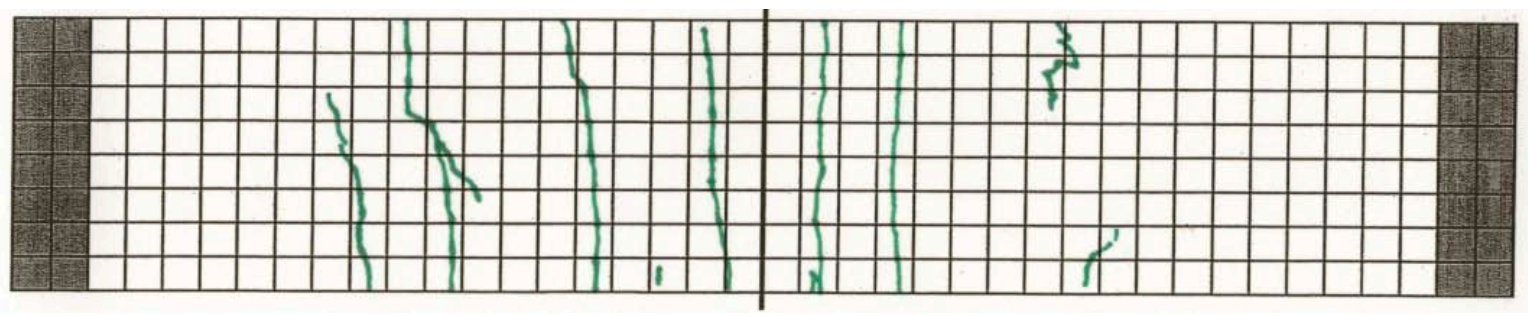

$1000 \mathrm{kN}$

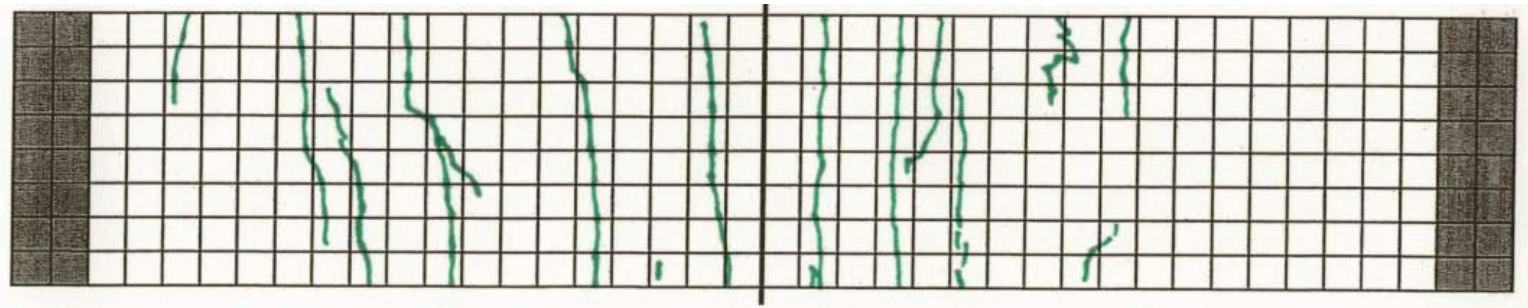

$1500 \mathrm{kN}$

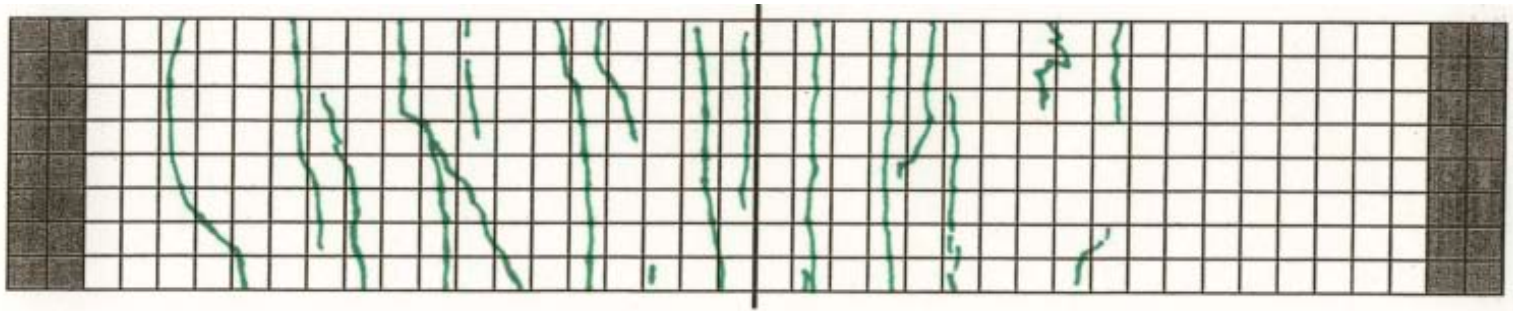

$2000 \mathrm{kN}$

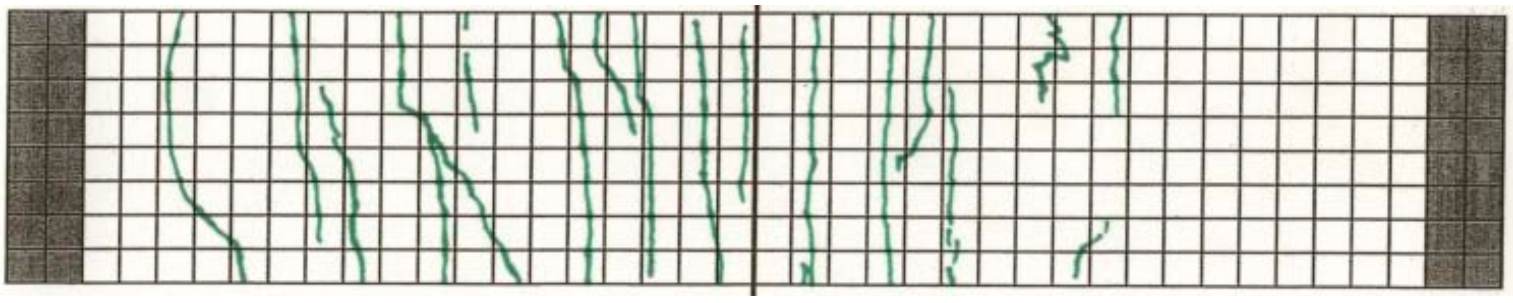

赤線 : 疲労試験時に入ったひび割れ，緑線 : 疲労試験後の静的載荷試験で入ったひび割れ，※計測メッシュ間隔は $100 \mathrm{~mm}$

図-4Ａ 体の静的載荷試験でのひび割れ図

中央の鋼析断面が降伏に至るまで静的載荷を行った。ひ ずみおよび変位を各荷重ステップで計測した。測定間 隔は約 1〜2 分間隔である.

\section{c) 計測方法}

測定は，スタッド基部の曲げひずみ，コンクリート 床版と鋼桁のずれ変位，床版の下鉄筋および鋼上フラ ンジのひずみについて行った．静的載荷試験の測定は, 各回測定時に初期值を原点として計測し, 各荷重ステッ プ時の除荷の結果を除いて掲載している。同様に B 体, $\mathrm{C}$ 体は, 疲労試験後に計測值を原点に戻して計測して いる、スタッドのひずみゲージの設置位置は，図-3に
示すように，スタッドと鋼桁フランジとの溶接部を避 け，フランジ上面より $2 \mathrm{~cm}$ 程度上のスタッド基部の表 裏に設置した。なお，ひずみは 2 ゲージの測定值の差 をとることで軸力の影響を除いている.

\section{3. コンクリート床版上面のひび割れ状況}

\section{(1) 計測結果}

コンクリート床版上面（実験では下側）のひび割れ 図を，A 体について図-4に，B 体について図-5に，C 体について図-6に示寸。 なお，図-4 は，A体の静的載 
CL

200kNの

疲労試験後

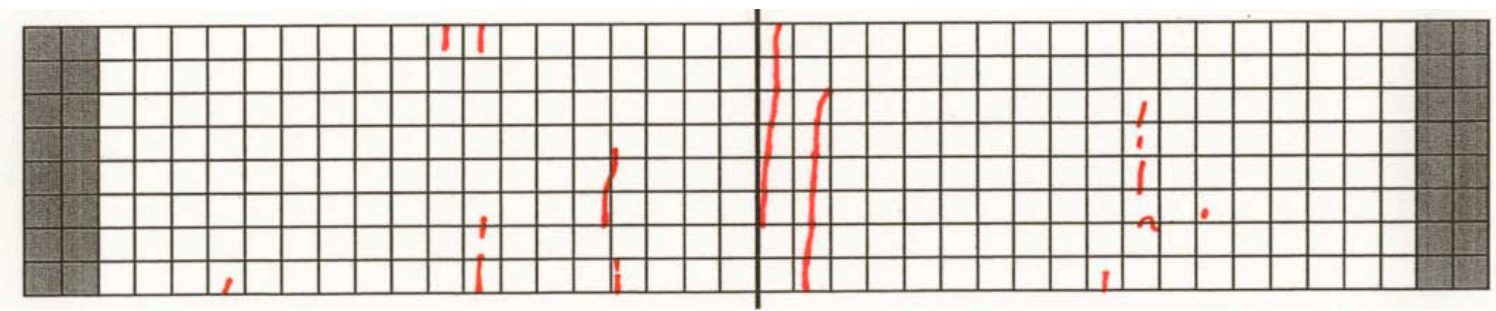

$600 \mathrm{kN}$

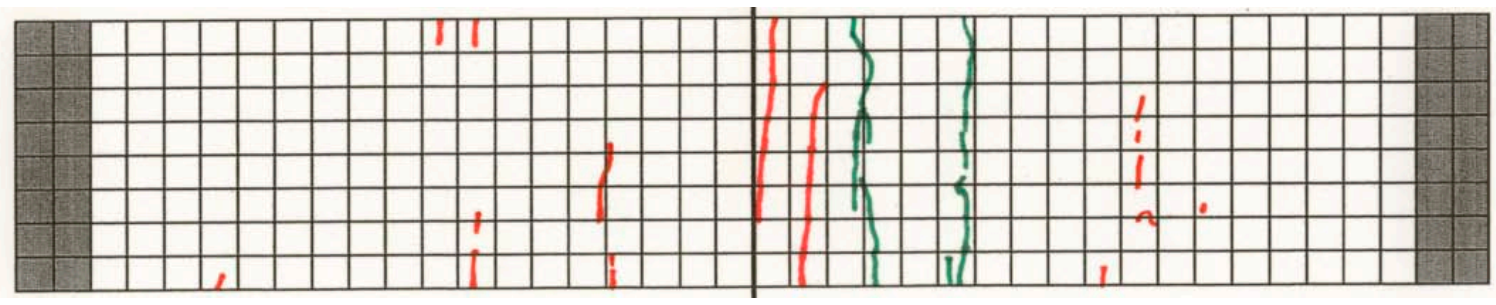

$1000 \mathrm{kN}$

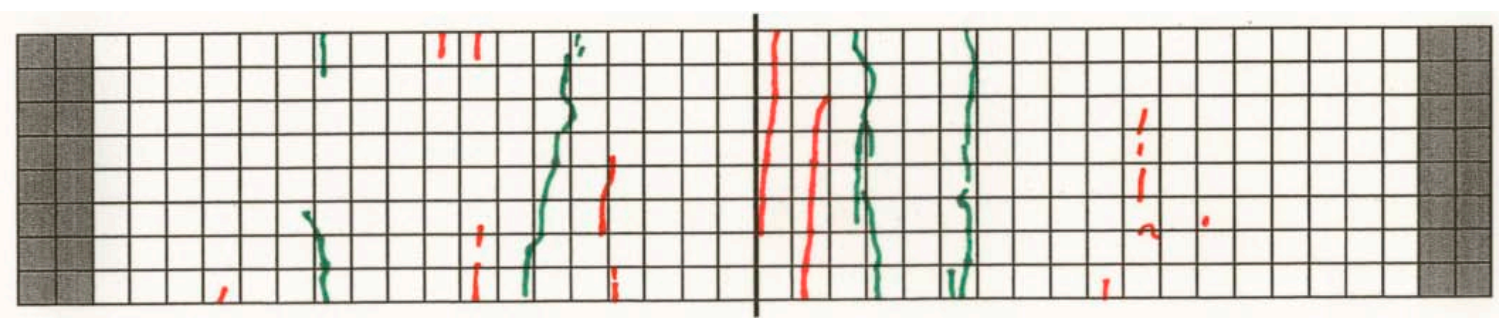

$1500 \mathrm{kN}$

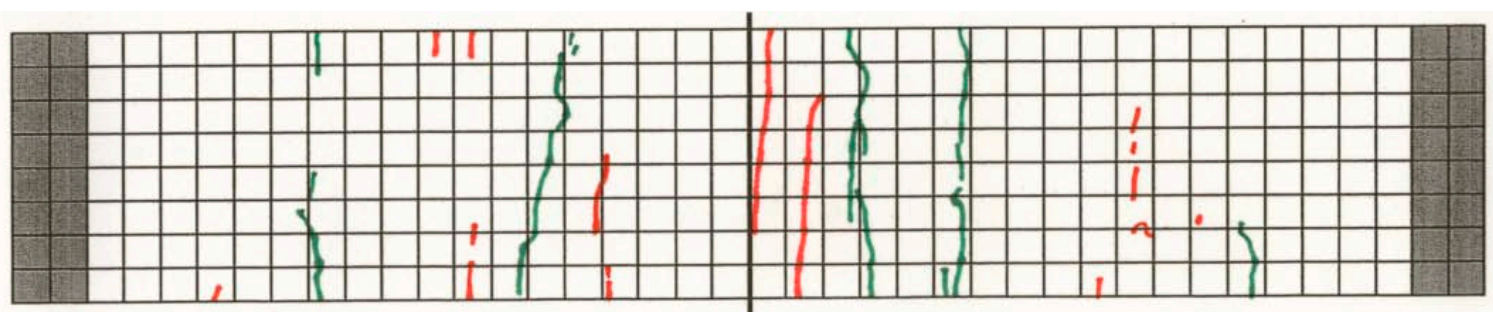

$2000 \mathrm{kN}$

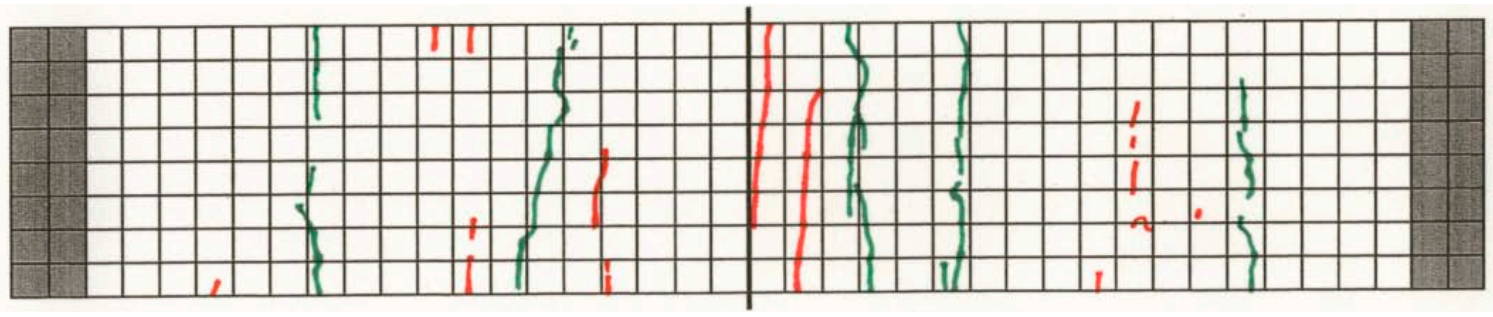

$2500 \mathrm{kN}$

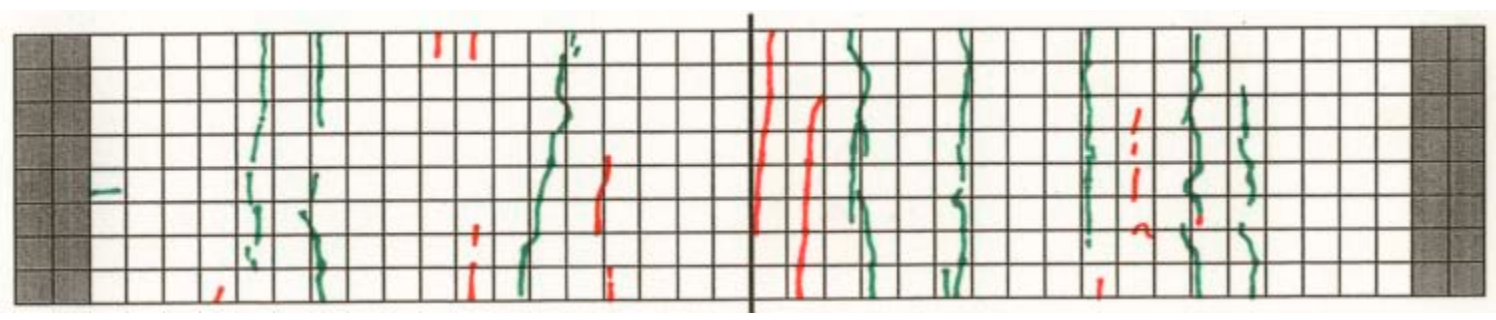

終局荷重

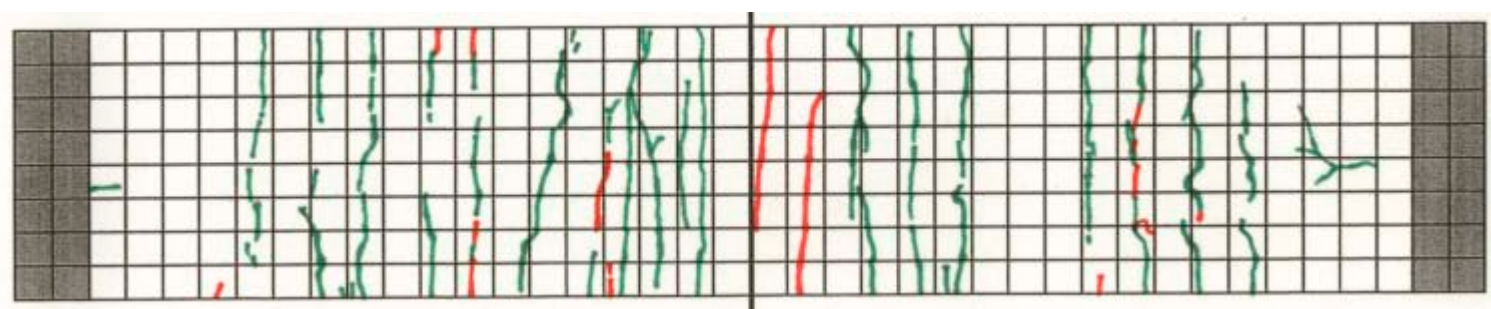

図-5 B 体の静的載荷試験でのひび割れ図 
CL

$600 \mathrm{kN} の$

疲労試験後

$1000 \mathrm{kN}$

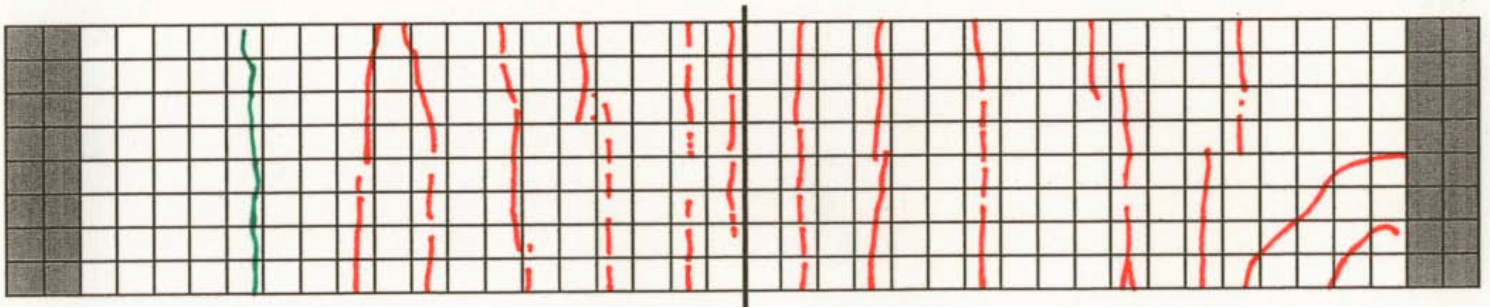

$1500 \mathrm{kN}$

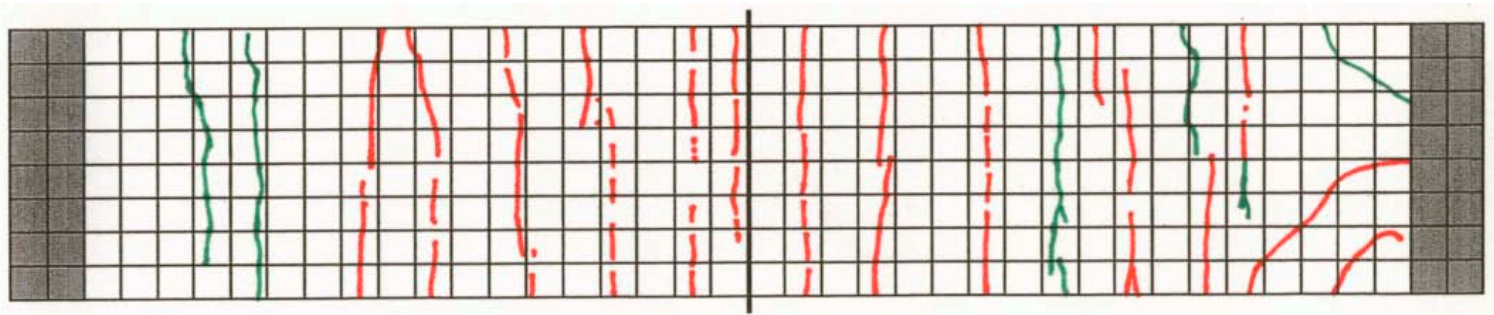

$2000 \mathrm{kN}$

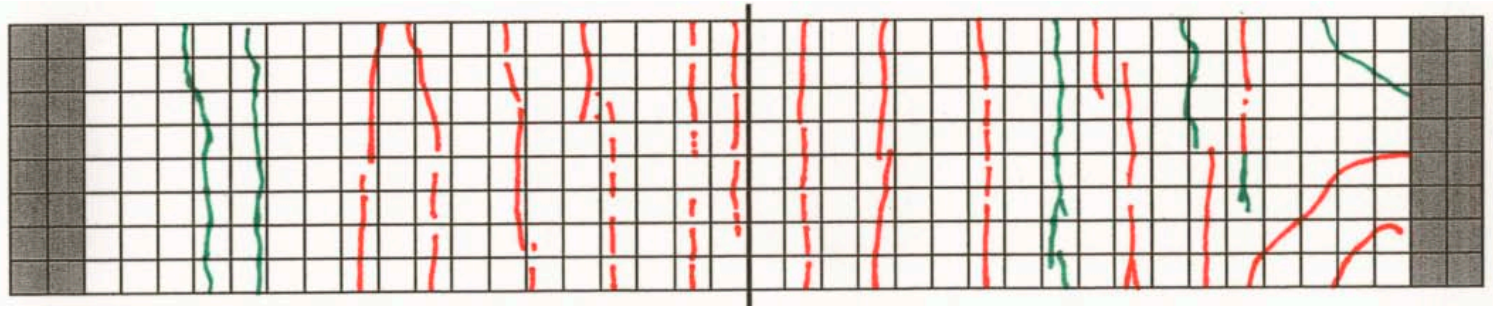

$2500 \mathrm{kN}$

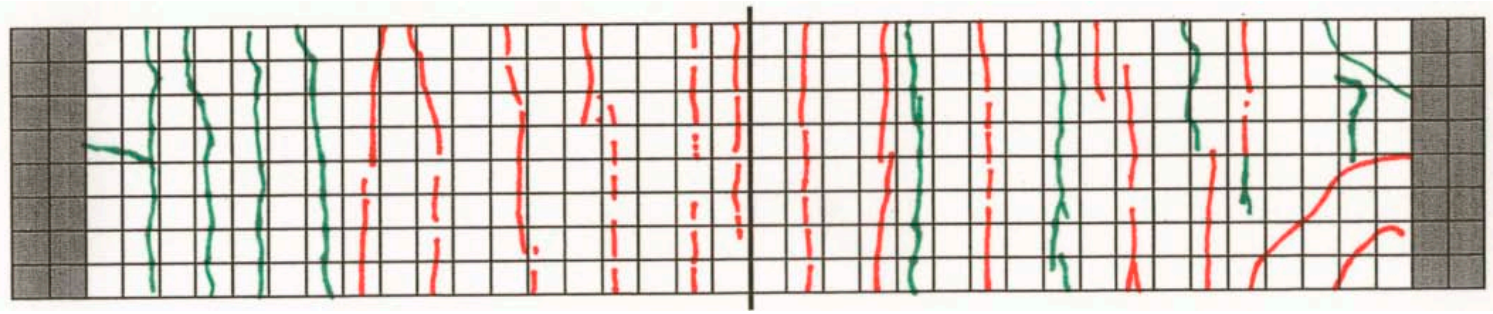

$3000 \mathrm{kN}$
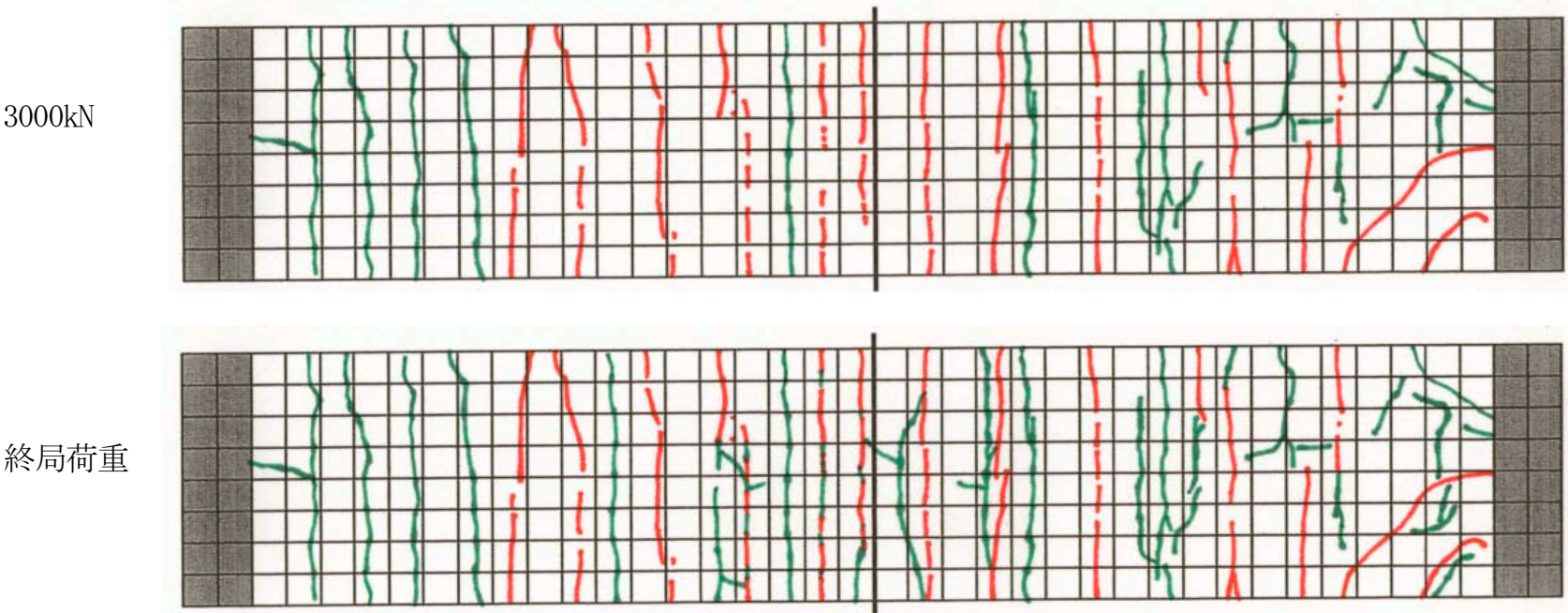

図-6 C 体の静的載荷試験でのひび割れ図 


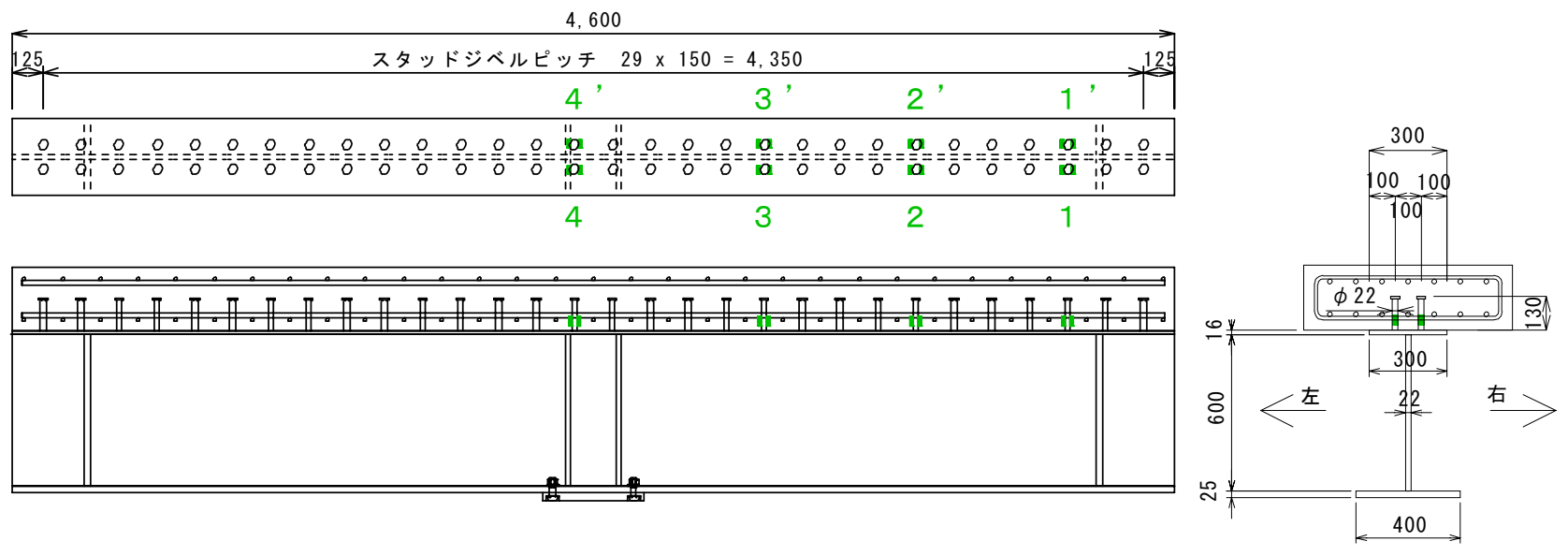

図-7 スタッド基部の曲げひずみの計測位置（単位 : mm）

荷試験における, 載荷荷重 $200 \mathrm{kN}, 600 \mathrm{kN}, 1000 \mathrm{kN}$, $1500 \mathrm{kN}, 2000 \mathrm{kN}$ でのひび割れの様子, 図-5 は，B 体 の, 疲労試験直後, および静的載荷試験における, 載荷 荷重 $600 \mathrm{kN}, 1000 \mathrm{kN}, 1500 \mathrm{kN}, 2000 \mathrm{kN}, 2500 \mathrm{kN}$, 終局載荷荷重でのひび割れの様子, 図-6は, C 体の, 疲労試験直後, および静的載荷試験における $1000 \mathrm{kN}$, $1500 \mathrm{kN}, 2000 \mathrm{kN}, 2500 \mathrm{kN}, 3000 \mathrm{kN}$, 終局載荷荷重 でのひび割れの様子を表している。 なお， B 体の載荷 荷重 $200 \mathrm{kN}, \mathrm{C}$ 体の載荷荷重 $200 \mathrm{kN}, 600 \mathrm{kN}$ について は, それぞれ, 疲労試験直後のひび割れの様子と変化 がなかったので，割愛している.

\section{(2) 考察}

図-4〜図-6より，ひび割れは枌中央付近から発生し 始め, 荷重が増加するに従い桁全体に広がると同時に, 発生したひび割れとひび割れの間に，新たなひび割れ が発生していることがわかる、ひび割れ発生位置は，お およそ主鉄筋間隔と一致している14),15)。疲労試験直後 をみると, 初期疲労載荷では, ひび割れは桁中央付近 に数本発生している程度であるが, 定常疲労載荷では, ほぼ桁全体に発生していることがわかる，新たなひび 割れは, A 体では $200 \mathrm{kN}$ から発生しているのに対し て, 初期疲労載荷では $600 \mathrm{kN}$ まで, 定常疲労載荷では $1000 \mathrm{kN}$ まで発生していない。これは, 疲労試験によ り，ある程度ひび割れが発生していたためと思われる。 また, A 体の $200 \mathrm{kN}$ の静的載荷後と, B 体の $200 \mathrm{kN}$ の 疲労載荷後を比べると，B 体の方が，ひび割れ本数は 多く, ひび割れ発生範囲も広い. 同じように, B 体の $600 \mathrm{kN}$ の静的載荷後と, C 体の $600 \mathrm{kN}$ の疲労載荷後を 比べると， C 体の方が，ひび割れ本数は多く，ひび割れ は桁全体に発生している。 このことから, 同じ載荷荷 重でも, 静的載荷と疲労載荷では, ひび割れの状況は 異なり, 疲労載荷の方が影響が大きいことがわかる.

\section{表-4 供試体の設計荷重値}

\begin{tabular}{c|c|c}
\hline 鋼標準 & \multicolumn{2}{|c}{ 複合指針 } \\
\hline 終局 & 終局限界 & ずれ限界 \\
\hline $801(\mathrm{kN})$ & $1870(\mathrm{kN})$ & $938(\mathrm{kN})$ \\
\hline
\end{tabular}

\section{4. スタッド基部の曲げひずみの挙動}

\section{（1）供試体の設計荷重値}

スタッド基部の曲げひずみの計測位置を図-7 に示す. 疲労載荷試験におけるスタッド基部の曲げひずみの挙 動を，B 体について図-8 に，C体について図-9 に示寸. 図中の 0 回は疲労試験前を表す。また, 静的載荷試験 におけるスタッド基部の曲げひずみの挙動を，A 体に ついて図-10に，B体について図-11に，C体について 図-12 に示寸（図中, $\mathrm{A} 1$ は A 体の測定位置 1 での曲げ ひずみの值を示す）。図中の鋼（終局）は，鉄道設計 標準13)の式 (鋼標準) 算定結果を, 複 (終局), 複（ず れ）はそれぞれ，土木学会「複合構造物の性能照查指 針（案）」16）（複合指針）の終局限界式，ずれ限界式算 定の結果を示している。供試体のスタッドにおける設 計荷重值を表-4 に示す，計算式は次のとおりである.

1）スタッド・鋼標準終局限界

$$
\frac{H}{d}=\frac{130}{22}=5.9>5.5
$$

より,

$$
\begin{gathered}
Q_{u}=16 \cdot d^{2} \sqrt{f_{c k}^{\prime}}=46(\mathrm{kN}) \\
Q_{a}=\frac{Q_{u}}{\gamma}=35(\mathrm{kN})
\end{gathered}
$$

ここに, $H$ : スタッドの高さ $(130 \mathrm{~mm})$

$d$ : スタッドの径 $(22 \mathrm{~mm})$

$f_{c k}^{\prime}$ : コンクリート圧縮強度

$\left(36.0 \mathrm{~N} / \mathrm{mm}^{2} \leftarrow\right.$ 実験結果)

$\gamma:$ 安全係数 (1.3) 


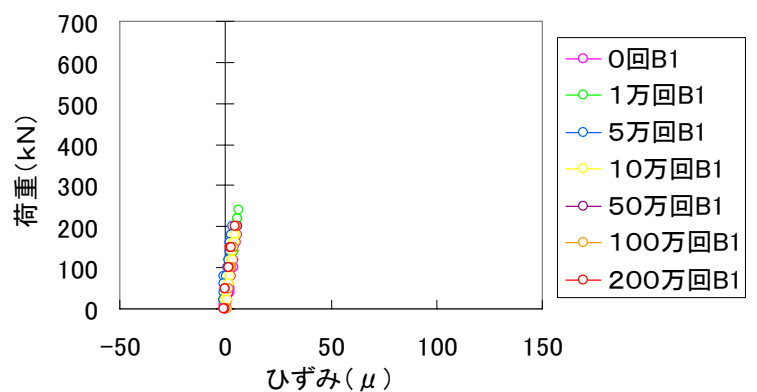

(a) B1

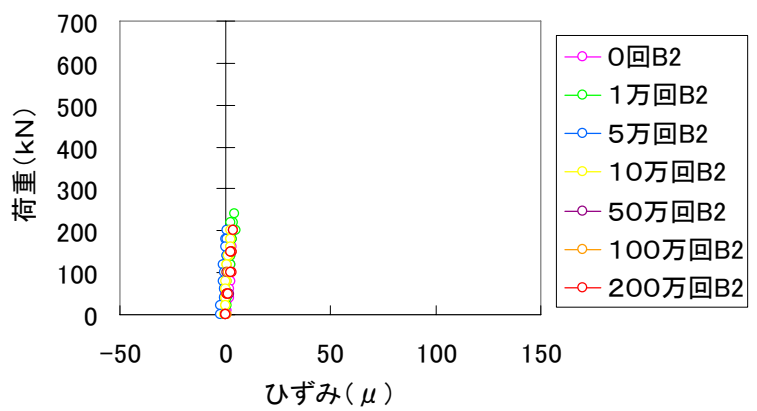

(b) B2

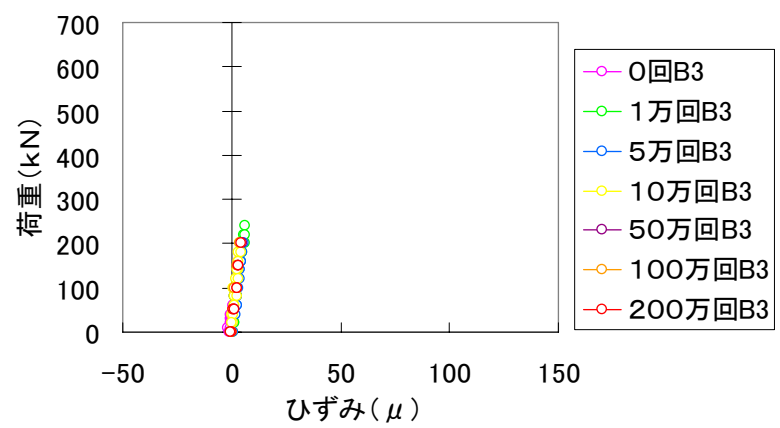

(c) B3

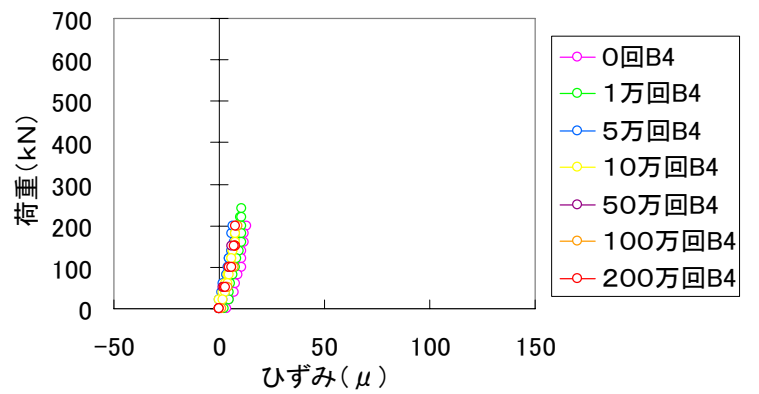

(d) B4

図-8 B 体のスタッドの基部の曲げひずみ

2）スタッド・複合指針終局限界

$$
\begin{gathered}
V_{\text {sud }}=\frac{31 A_{s s} \sqrt{\left(h_{s s} / d_{s s}\right) f_{c d}^{\prime}}+10000}{\gamma_{b}}=140(\mathrm{kN}) \\
V_{\text {sud }}=\frac{0.7 A_{s s} f_{\text {sud }}}{\gamma_{b}}=82(\mathrm{kN})
\end{gathered}
$$

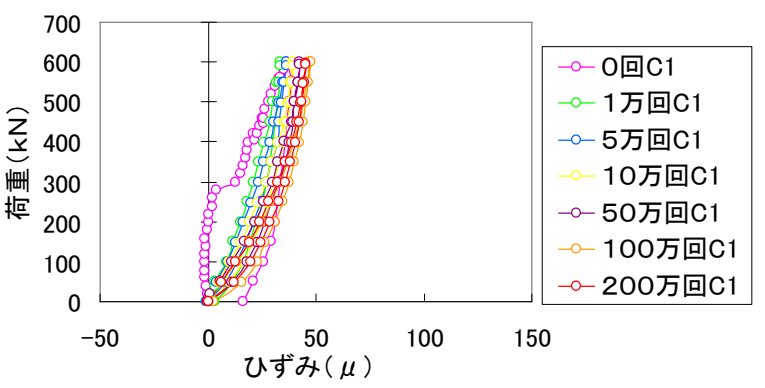

(a) $\mathrm{C} 1$

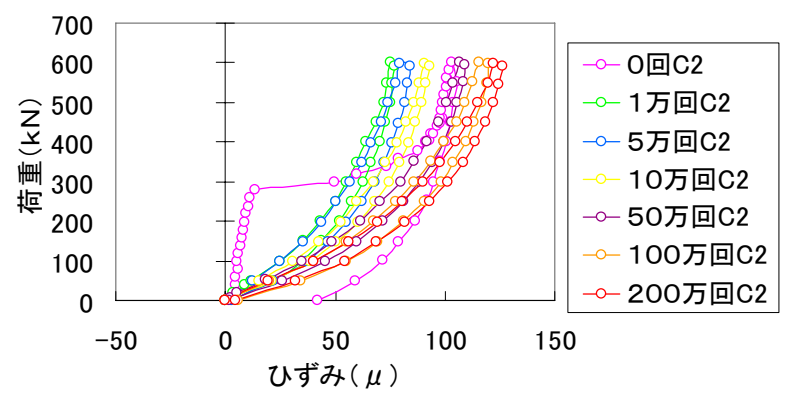

(b) $\mathrm{C} 2$

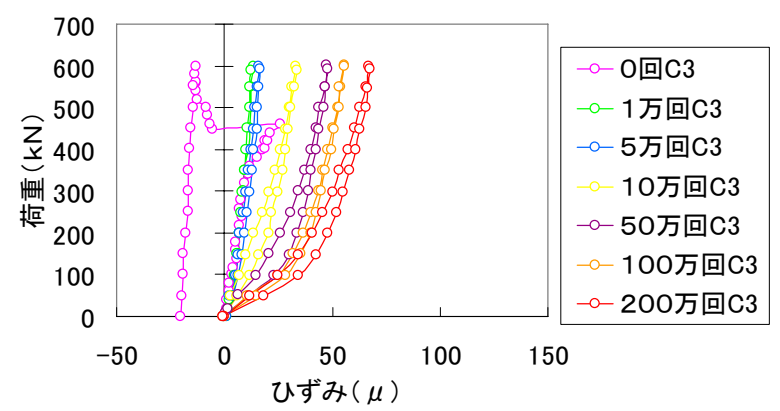

(c) $\mathrm{C} 3$

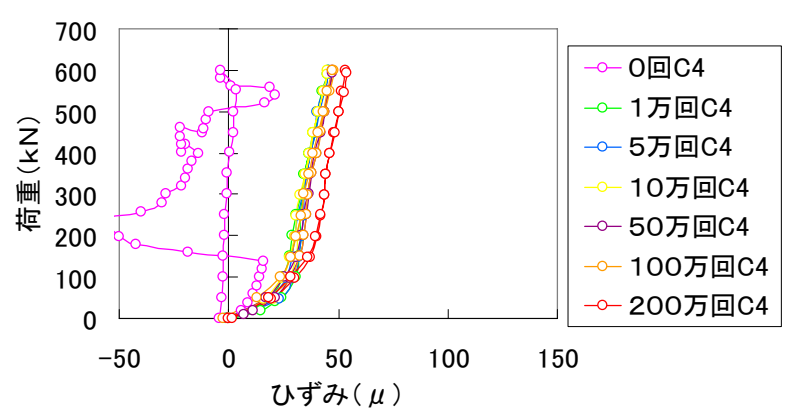

(d) $\mathrm{C} 4$

図-9 C 体のスタッド基部の曲げひずみ

ここに, $A_{s s}$ : スタッドの断面積 $\left(\mathrm{mm}^{2}\right)$

$h_{s s}$ : スタッドの高さ $(130 \mathrm{~mm})$

$d_{s s}$ : スタッドの径 $(22 \mathrm{~mm})$

$f_{c d}^{\prime}$ : コンクリート圧縮強度

$\left(36.0 \mathrm{~N} / \mathrm{mm}^{2} \leftarrow\right.$ 実験結果)

$f_{\text {sud }}$ : スタッドの設計引張強度

$\left(400 \mathrm{~N} / \mathrm{mm}^{2} \leftarrow\right.$ 実強度 $)$

$\gamma_{b}$ : 部材係数 $(1.3)$

式(4)または式(5)のうちで小さい方とする. 


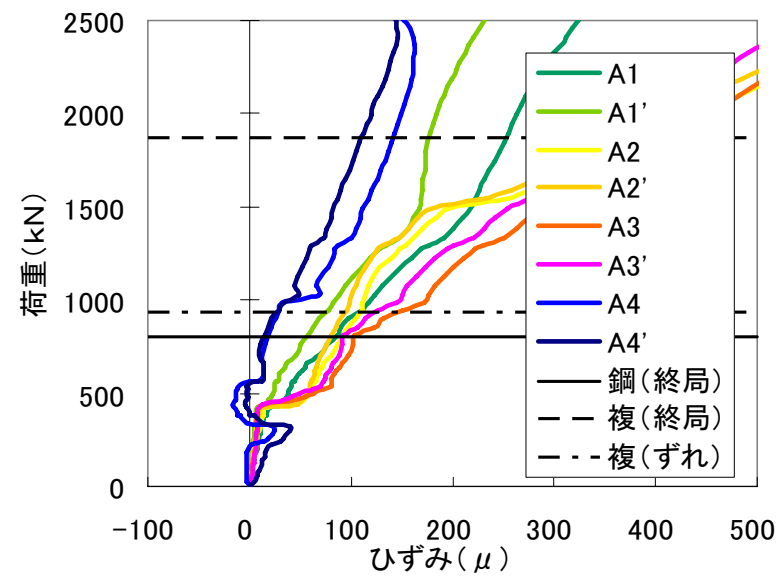

図-10 A 体のスタッド基部の曲げひずみ

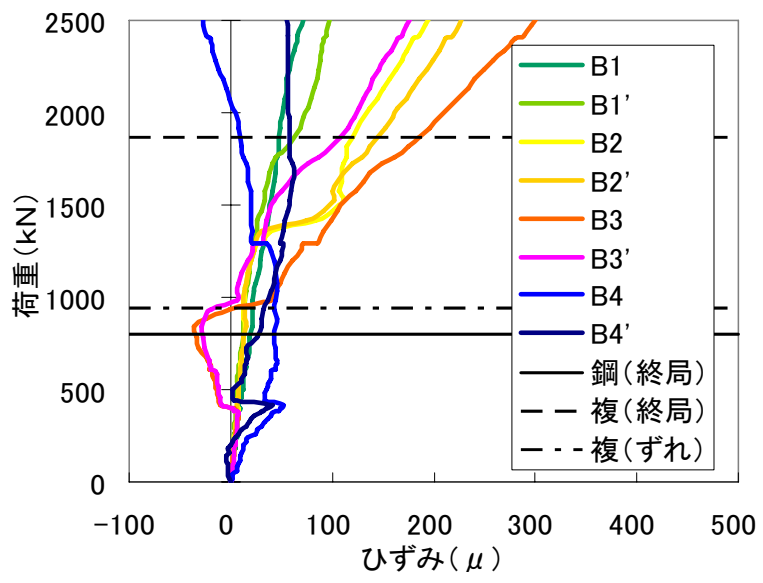

図-11 B 体のスタッド基部の曲げひずみ

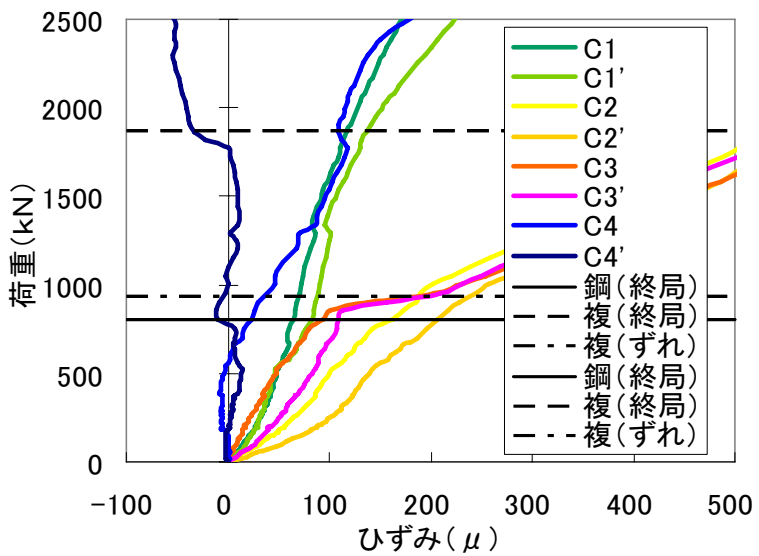

図-12 C 体のスタッド基部の曲げひずみ

3）スタッド・複合指針ずれ限界

打設方法 A タイプより，

$$
V_{\text {scd }}=0.5 V_{\text {sud }}=41(\mathrm{kN})
$$

1）～3）の值を供試体の鉛直荷重に換算する.
単位長さあたりのせん断力 $H$

$$
H=\frac{a Q}{b}
$$

ここに, $a$ : スタッド配置列数 (2)

$Q$ : スタッド 1 本あたりのせん断力 $(\mathrm{kN})$

$b$ : スタッドの橋軸方向間隔 $(150 \mathrm{~mm})$

せん断力 $H$ と鉛直荷重 $P$ の関係

$$
H=\frac{Z_{0} A_{c} / n}{I_{0}} \times S
$$

ここに, $Z_{0}$ : 合成断面における中立軸から床版中心ま での距離 $(231 \mathrm{~mm})$

$I_{0}$ : 合成断面の断面二次モーメント $\left(\mathrm{mm}^{4}\right)$

$A_{c}$ : コンクリート床版断面積 $\left(\mathrm{mm}^{2}\right)$

$n:$ 鋼とコンクリートのヤング係数比 $(7)$

$S$ : せん断力 $($ 単純枌 $・$ 集中荷重 : $=P / 2)$

より,

$$
P=2 H \frac{I_{0}}{Z_{0} A_{c} / n}
$$

\section{(2) 考察}

図-8, 図-9より，200 kN の初期疲労載荷では，曲げ ひずみが急変することはなく, $600 \mathrm{kN}$ の定常疲労載荷 では，疲労試験前の予備載荷時において，荷重が 300〜 $400 \mathrm{kN}$ でひずみが急変している。また，図-9より，疲 労回数が増加するに従い, ひずみは増加する傾向にある ことがわかる：これらのことから，荷重が $300 〜 400 \mathrm{kN}$ で，スタッド基部とコンクリートとの付着が切れたと 思われ, その結果, 作用に対するスタッドの負担が増加 するため, 疲労回数が増加するに従い, ひずみが増加す るものと思われる. なお, ひずみゲージ位置はスタッド 基部より $2 \mathrm{~cm}$ 上方にずれているので, スタッド基部と コンクリートとの付着切れは, 荷重が 300〜 400 kN よ り早い段階で発生している可能性がある.

図-10〜図-12より，桁中央（4-4'断面）の曲げひず みが最も小さいことがわかる。これは，桁中央はせん断 力が小さいためと思われる。ただし，ひずみの急変が 現れるのは最も早い傾向にある.これは, 桁中央から 発生するひび割れの影響を受けたものと思われる．桁 中央から $600 \mathrm{~mm}$ 離れた位置（3-3'断面）での曲げひ ずみが最も大きく, 桁端（1-1'断面）に向かって小さ くなっている.これは，これらの位置でのせん断力は 等しいことから，ひび割れの発生の影響を受けたため と思われ，ひび割れの本数の少ない桁端の曲げひずみ が小さい傾向にあることがわかる．A4，A4' は荷重が $300 \mathrm{kN}$ 前後で, B3, B3' は荷重が $400 \mathrm{kN}$ 前後, および $1000 \mathrm{kN}$ 前後で，B4，B4' は荷重が $400 \mathrm{kN}$ 前後，およ び $1300 \mathrm{kN}$ 前後でひずみの正負が逆転している.これ は，測定位置周辺のコンクリートにひび割れが発生し たため，その影響を受けたことによると思われる．設計 


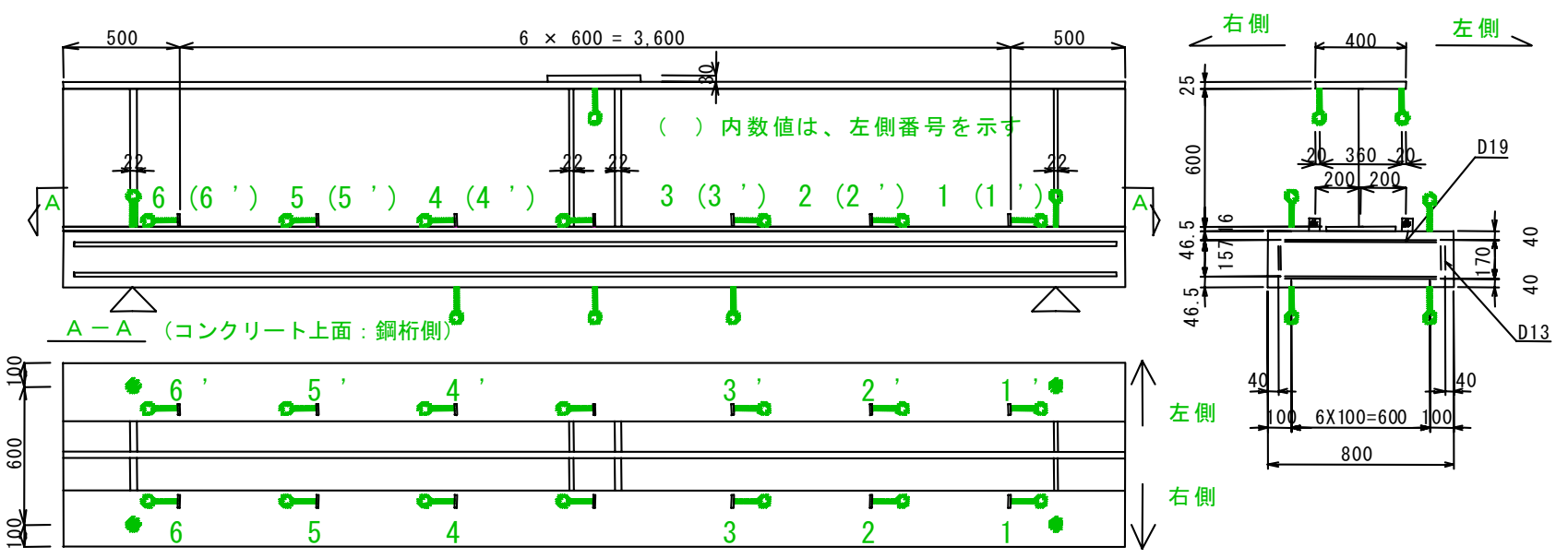

図-13 鉛直変位およびずれ変位の計測位置（単位：mm）

值との比較では, 最も小さな值となっている鋼標準式 $(801 \mathrm{kN})$ よりも小さな範囲で, ひずみが急変している. 特にせん断力の小さな A4, A4', B4, B4' でも急変し ており，ひび割れの発生の影響を受けていることがわ かる、また，図-10より，A 体のスタッド基部の曲げひ ずみは, A2, A2', A3, A3', A4, A4'において, 荷重 が 300〜 400 kN 前後で急変しているが, これは, この 時点で，スタッド基部とコンクリートとの付着が切れ たものと思われる. 図-11の, B 体のスタッド基部の曲 げひずみについても, 桁中央付近の B3, B3', B4, B4' において, 荷重が $400 \mathrm{kN}$ 前後で急変しており, 同様の 傾向を示している. 図-12のC 体では, 最初からひず みが大きく増加している。これは， $600 \mathrm{kN}$ の定常疲労 載荷により，鋼桁とコンクリートとの付着が切れたと 思われ，そのため最初から作用に対するスタッドの負 担が増加していると思われる. 図-9の疲労載荷回数 1 万回以上の測定結果も同様の傾向を示しており, 疲労 試験前の予備載荷時に鋼桁とコンクリートとの付着が 切れたため, 最初から作用に対するスタッドの負担が 増加していると思われる.

図-12より，C体の曲げひずみの大きさは，おおよそ C3，C2，C1，C4の順に大きい傾向を示しているが，図9では, C2, C3, C4, C1 の順となっている.これは, 図-9は, 定常疲労載荷中の值であり, 図-12 は定常疲 労載荷後の值であるためと思われる.つまり, 図-6の, $600 \mathrm{kN}$ の疲労試験後のひび割れ図からもわかるように, 定常疲労載荷中に, C2, C4 の測定位置付近のコンク リートにひび割れが入ったため, 図-9において C2, C4 の值が大きくなったと思われる. 図-10, 図-11のA 体, B 体についても， $600 \mathrm{kN}$ 以下の荷重では，ひび割れの 影響を受けるため, ひずみの大きさは $3 ， 2 ， 1,4$ の順 ではなく, 乱れが生じており, 同様の傾向を示してい る. 定常疲労載荷後は, ある程度ひび割れが出揃ってし まうため, ひび割れ発生の影響が小さくなり, 図-10〜
図-12 の $600 \mathrm{kN}$ 以上の荷重では，おおよそ 3, 2, 1, 4 の順になっている.

以上のことから，ひび割れが入ることにより，作用 に対するスタッドの負担が増加するため, その結果, ス タッド基部とコンクリートの付着が切れるものと推察 される.このスタッド基部とコンクリートの付着切れ は，表-4の押し抜きせん断で決定された值以下で発生 していると考えられる.ただし，表-4の值は正曲げで の值であり，ひび割れが入らないことが前提の值であ る.これらのことから, 負曲げを受ける中間支点部で は，ひび割れの影響により，正曲げに比べ小さい荷重 で，スタッド基部とコンクリートの付着が切れる場合 があり, 現状の耐力式でスタッドの耐力を評価しても 問題ないが，付着を期待することはできない.

\section{5. コンクリート床版と鋼林のずれ変位}

コンクリート床版と鋼桁のずれ変位の計測位置は図13 に示したとおりである. 静的載荷時におけるコンク リート床版と鋼桁のずれ変位の挙動を, A 体について 図-14に, B 体について図-15に, C 体について図-16に 示す.

図-14〜図-16より, A 体は $500 \mathrm{kN}$ 前後, B 体は $1000 \mathrm{kN}$ 前後 $(500 \sim 1500 \mathrm{kN}), \mathrm{C}$ 体は $2000 \mathrm{kN}$ 前後 (1500～2500 kN） でずれ変位の勾配が変化している. また,ずれ変位の勾配が変化した後の荷重一ずれ変位 曲線の傾きは, 多少のばらつきはあるものの, A 体, B 体, C体ともに, 同じような勾配であり, ずれ変位の挙 動は，供試体によらず同じような傾向を示すことがわ かる.さらに, A 体は $500 \mathrm{kN}$ 前後, B 体は $1000 \mathrm{kN}$ 前 後, $\mathrm{C}$ 体は $2000 \mathrm{kN}$ 前後まで, ずれ変位がほとんど生 じずほぼ鉛直に延びている。これは，A 体については $500 \mathrm{kN}$ 前後で, B 体については $1000 \mathrm{kN}$ 前後で, C 体 については $2000 \mathrm{kN}$ 前後で, 計測位置でのコンクリー 


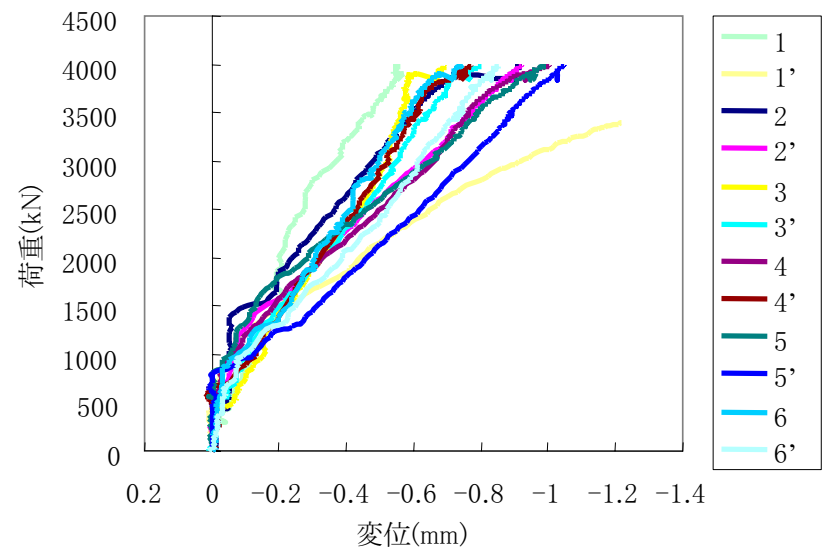

図-14 A 体のずれ変位

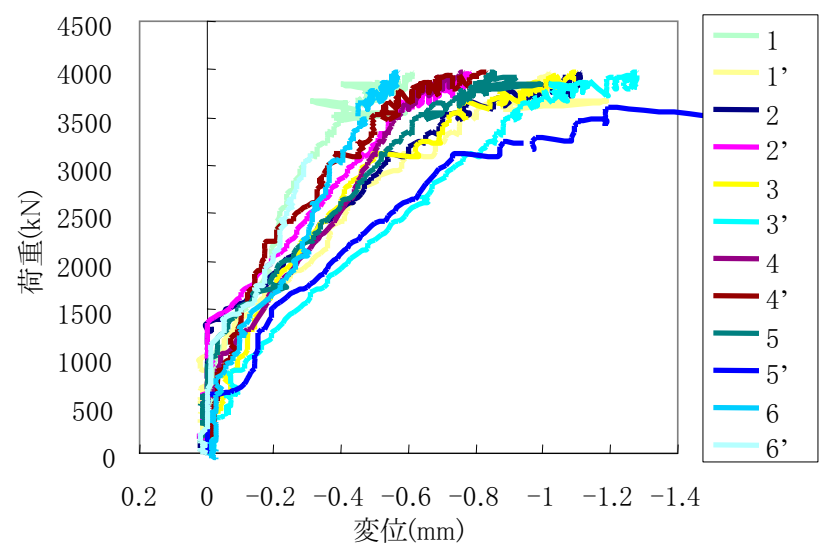

図-15 B 体のずれ変位

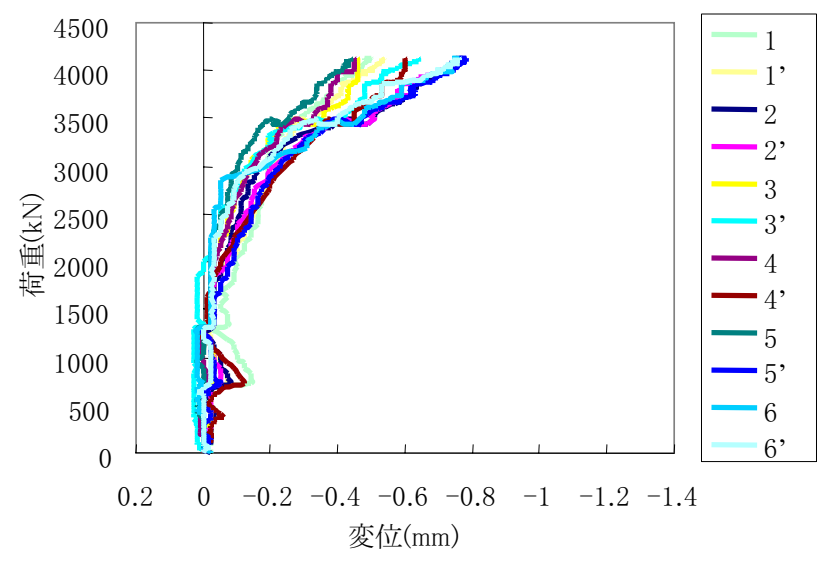

図-16 C 体のずれ変位

トと鋼桁との間にずれが生じ始めたものと思われる。ま た， B 体，C体については，図-5, 図-6からわかるよ うに, 疲労荷重載荷によりひび割れが発生している。そ の後の静的荷重載荷の初期段階では, 既存のひび割れ 位置でずれが集中し，ひび割れ位置以外（計測位置）で はずれ変位が小さいと考えられる.つまり, 静的荷重載 荷の初期段階では, 疲労載荷荷重によってすでに発生

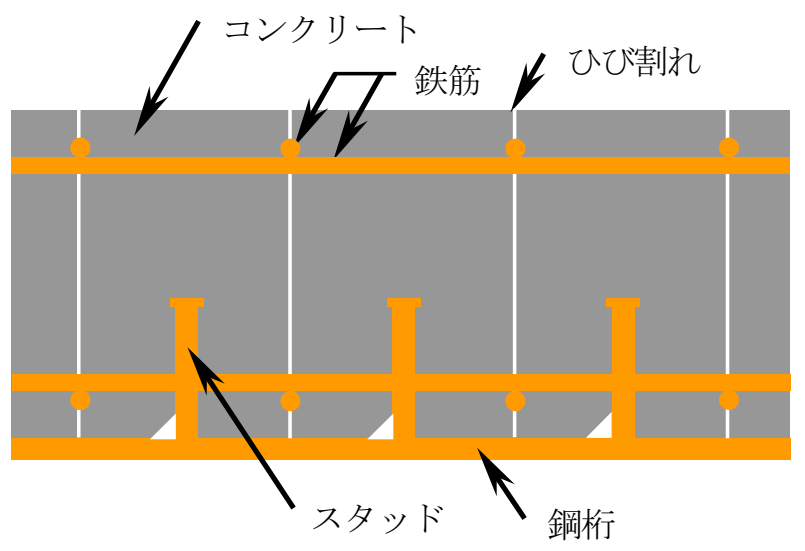

図-17 ひび割れ後のコンクリート床板のモデル図

したひび割れがずれを吸収するため,ひび割れが発生 していない箇所での，コンクリートと鋼林とのずれの 発生は遅れるものと思われる. 既存のすべてのひび割 れがずれを吸収した後, 新たなひび割れの発生ととも に，コンクリートと鋼林のずれが生じ始めるため，既 存のひび割れ本数の多いC 体の方が, 既存のひび割れ 本数の少ない $\mathrm{B}$ 体よりも, ずれ発生が遅れるものと考 えられる，ただし， B 体， C 体は, 疲労試験後にずれ変 位を原点に戻して終局載荷時におけるずれ変位を計測 しているため, 疲労試験前からのずれ変位の合計值は, $\mathrm{C}$ 体のずれ変位が最も大きく, A 体が最も小さいと考 えられる。

ひび割れが発生した後のコンクリート床版の様子は, 図-17 のモデル図に示すように, 橋軸直角方向鉄筋上に 発生したひび割れによって分割された，それぞれのコ ンクリートブロックが, 互いに軸方向鉄筋によって連 結され，スタッドによって鋼桁と連結されていると推 察される. 図-4〜図-6からもわかるように，ひび割れ は, 最初のひび割れ発生位置から, ある一定の方向に 向かって順次発生するのではなく，ある間隔でひび割 れが発生後, 発生したひび割れとひび割れの間に, 新 たなひび割れが発生している. 新たなひび割れの発生 は, ひび割れの発生したコンクリートブロックに引張 力が生じていたことを示し, 寸なわち, 新たなひび割 れが発生する直前までは, 引張耐力がゼロになるわけ ではなく, テンションスティフニングの効果があると 考えられる. 定常ひび割れ状態に達した後は, しばら くは新たなひび割れが発生しないことから, 定常ひび 割れ状態以降は, テンションスティフニングの効果は 小さいと思われる。しかし, 定常ひび割れ状態に達す るまでは, 新たなひび割れが発生しており, 新たに発 生するひび割れのひび割れ幅は, $0.2 \mathrm{~mm}$ 以下に収まっ ている17)ことから, テンションスティフニングの効果 が期待できると考えられる. 


\section{6. 床版の下鉄筋の荷重ーひずみの関係 \\ (1) 計測結果}

床版の下鉄筋のひずみの，上面から見た計測位置を 図-18に，床版断面図を図-19に示す.静的載荷試験に おける床版の下鉄筋の荷重一ひずみの関係について，荷 重 $600 \mathrm{kN}$ 以下の様子を, 中心から $200 \mathrm{~mm}$ 離れた断面 $\mathrm{a}$ について図-21に, 中心から $600 \mathrm{~mm}$ 離れた断面 $\mathrm{b}$ に ついて図-22に，鉄筋のひずみ理論線概略図を図-23に 示す. $\varepsilon_{s m}$ は, Hanswille の理論に基づく最大ひずみと 平均ひずみの計算式から算出した值であり, 図-23のよ うに仮定した. ‘鋼析十鉄筋” はコンクリートを無視し た岡性（鋼桁十鉄筋断面）における計算值である. 乾燥 収縮ひずみは, 通常の設計で用いられている值として, $\varepsilon_{s h}=150 \mu \mathrm{m}$ と設定した. 断面 $\mathrm{a}, \mathrm{b}$ の各ひずみの值 は, 図-18に示方左右 1)〜3）の平均值である. C 体の

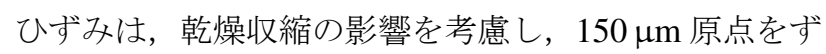
らしている. 実験供試体断面図と計算仮定を図-20に, 各断面のひび割れ発生荷重を表-5に，定常ひび割れ開 始時のひずみを表-6に示す。計算式は次のとおりであ る. なお，式(16), (20) における $\beta$ はテンションスティ フニングの大きさを表す係数であり, EUROCODE 4 ${ }^{2)}$ を参照に, 定常ひび割れ時において, 疲労試験を行って いない供試体では $\beta=0.4$, 疲労試験を行った供試体で は $\beta=0.2$ と設定している11).

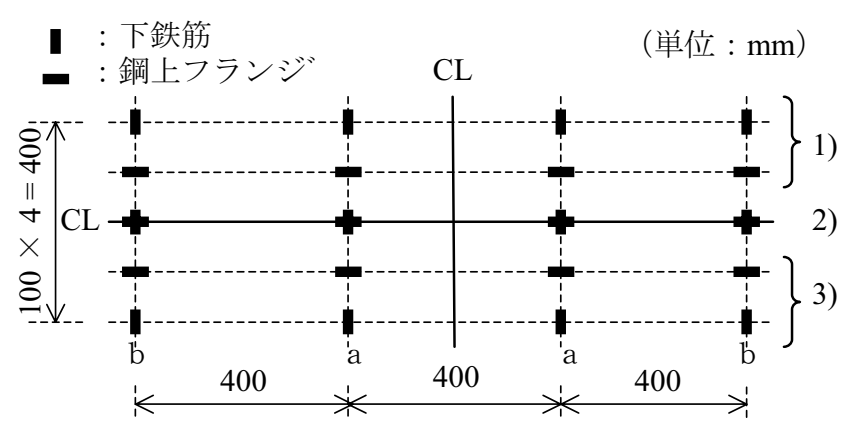

図-18 下鉄筋および鋼上フランジのゲージ配置図

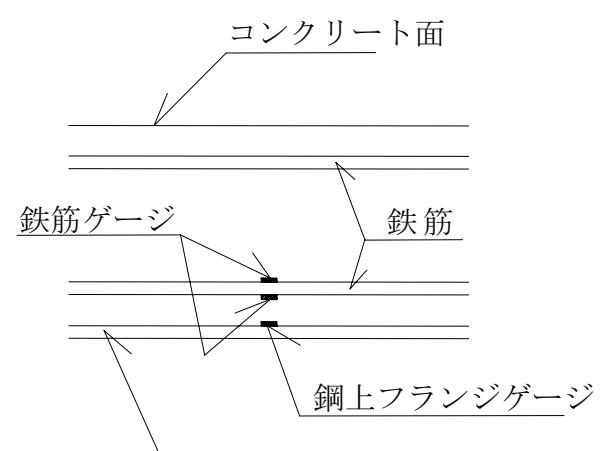

鋼上フランジ

図-19 床版断面図
【初期ひび割れ発生荷重】

合成断面中立軸とコンクリート床版上縁との距離

$$
y_{c}^{\prime \prime}=Z_{0}+\frac{h_{c}}{2}
$$

初期ひび割れ発生モーメント

$$
M_{c r}=\frac{f_{t}}{y_{c}^{\prime \prime}} I_{0}^{\prime}
$$

初期ひび割れ発生荷重

$$
P_{c r}=\frac{4 M_{c r}}{L}
$$

$L$ : スパン $(\mathrm{a}$ 断面 $=360 \mathrm{~cm}, \mathrm{~b}$ 断面 $=280 \mathrm{~cm}$ )

【定常ひび割れ発生荷重】

$$
\begin{aligned}
k_{c}=k_{c 0}+0.3 & =\frac{1}{1+h_{c} / 2 Z_{0}}+0.3 \\
\alpha & =\frac{A_{1} I_{1}}{A_{g} I_{g}}
\end{aligned}
$$

ひび割れ軸力

$$
N_{s c r}=f_{t} k_{c} A_{c}\left(1+n \rho_{s}\right)
$$

定常ひび割れ発生モーメント

$$
M_{s t}=\left(N_{s c r}-\beta \frac{f_{t} A_{s}}{\rho_{s} \alpha}\right) \frac{I_{1}}{A_{s} Z_{1}}
$$

定常ひび割れ発生荷重

$$
P_{s t}=\frac{4 M_{s t}}{L}
$$

\section{【鉄筋のひずみ】}

ひび割れ発生直前ひずみ $\varepsilon_{c r}$

$$
\varepsilon_{c r}=\frac{f_{t}}{E_{c}}
$$

ひび割れ発生後の最大ひずみ $\varepsilon_{s 2 s t}$ （=定常ひび割れ 開始時の最大ひずみ)

$$
\varepsilon_{s 2 s t}=\frac{N_{s c r}}{E_{s} A_{s}}+\varepsilon_{s h}
$$

定常ひび割れ開始時の平均ひずみ $\varepsilon_{s m s t}$

$$
\varepsilon_{s m s t}=\varepsilon_{s 2 s t}-\beta \frac{f_{t}}{E_{s} \rho_{s}}
$$

ひび割れ発生直後の平均ひずみ $\varepsilon_{s m c r}$

$$
\varepsilon_{s m c r}=\varepsilon_{s 2 s t}-0.6 \frac{f_{t}}{E_{s} \rho_{s}}
$$

\section{表-5 各断面のひび割れ発生荷重}

\begin{tabular}{c|c|c|c}
\hline & $\begin{array}{c}\text { 初期ひび割れ } \\
\text { 発生荷重 }(\mathrm{kN})\end{array}$ & \multicolumn{2}{|c}{$\begin{array}{c}\text { 定常ひび割れ発生荷重 } \\
(\mathrm{kN})\end{array}$} \\
\hline$\beta$ & - & 0.4 & 0.2 \\
\hline $\mathrm{a}$ 断面 & 303 & 693 & 788 \\
\hline $\mathrm{b}$ 断面 & 390 & 892 & 1013 \\
\hline
\end{tabular}

表-6 鉄筋の定常ひび割れ開始時のひずみ

\begin{tabular}{c|c|c}
\hline$\beta$ & 0.4 & 0.2 \\
\hline 平均ひずみ $(\mu \mathrm{m})$ & 566 & 688 \\
\hline 鋼桁十鉄筋断面のひずみ $(\mu \mathrm{m})$ & 670 & 740 \\
\hline
\end{tabular}



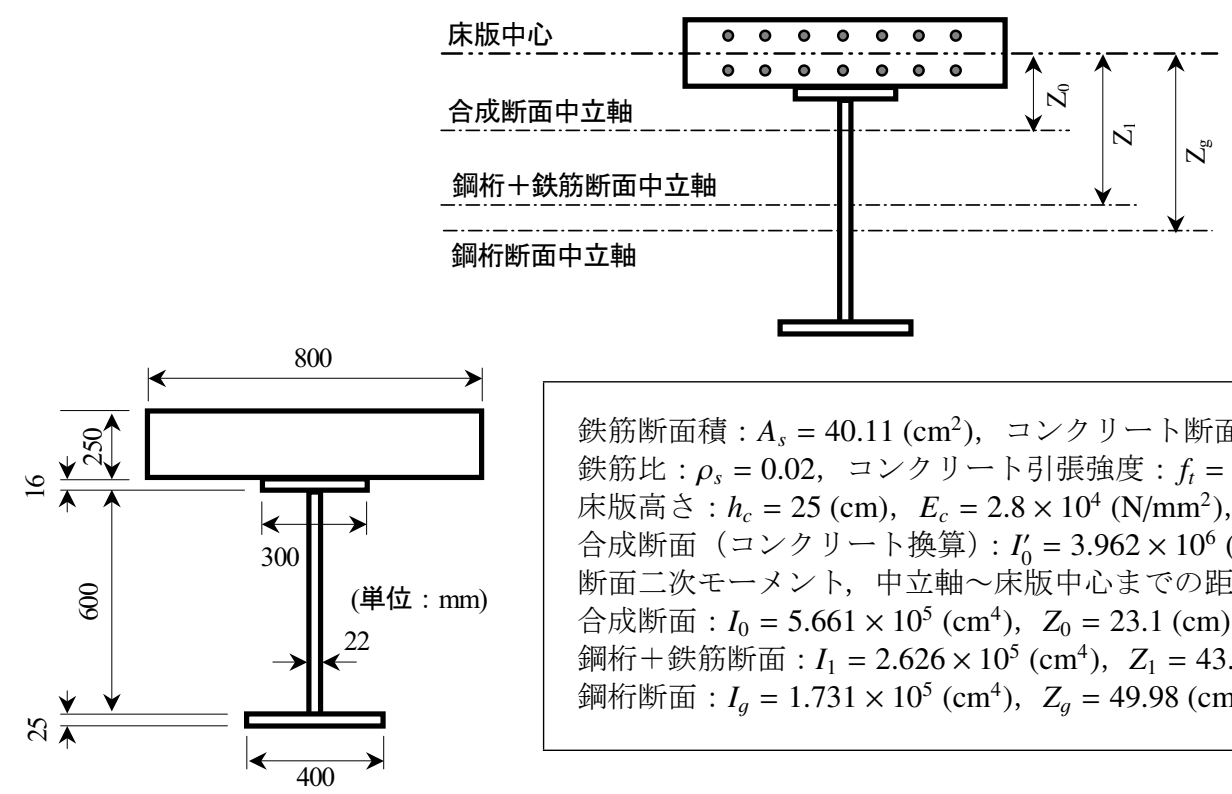

鉄筋断面積: $A_{s}=40.11\left(\mathrm{~cm}^{2}\right)$, コンクリート断面積 : $A_{c}=2000\left(\mathrm{~cm}^{2}\right)$

鉄筋比 : $\rho_{s}=0.02$, コンクリート引張強度 : $f_{t}=2.45\left(\mathrm{~N} / \mathrm{mm}^{2}\right)$

床版高さ : $h_{c}=25(\mathrm{~cm}), E_{c}=2.8 \times 10^{4}\left(\mathrm{~N} / \mathrm{mm}^{2}\right), E_{s}=2.0 \times 10^{5}\left(\mathrm{~N} / \mathrm{mm}^{2}\right)$

合成断面（コンクリート換算）: $I_{0}^{\prime}=3.962 \times 10^{6}\left(\mathrm{~cm}^{4}\right)$

断面二次モーメント, 中立軸〜床版中心までの距離, 断面積

合成断面 : $I_{0}=5.661 \times 10^{5}\left(\mathrm{~cm}^{4}\right), Z_{0}=23.1(\mathrm{~cm})$

鋼枌 + 鉄筋断面: $I_{1}=2.626 \times 10^{5}\left(\mathrm{~cm}^{4}\right), Z_{1}=43.717(\mathrm{~cm}), A_{1}=320.11\left(\mathrm{~cm}^{2}\right)$

鋼桁断面 : $I_{g}=1.731 \times 10^{5}\left(\mathrm{~cm}^{4}\right), Z_{q}=49.98(\mathrm{~cm}), A_{q}=280\left(\mathrm{~cm}^{2}\right)$

\section{図-20 実験供試体断面図と計算仮定}

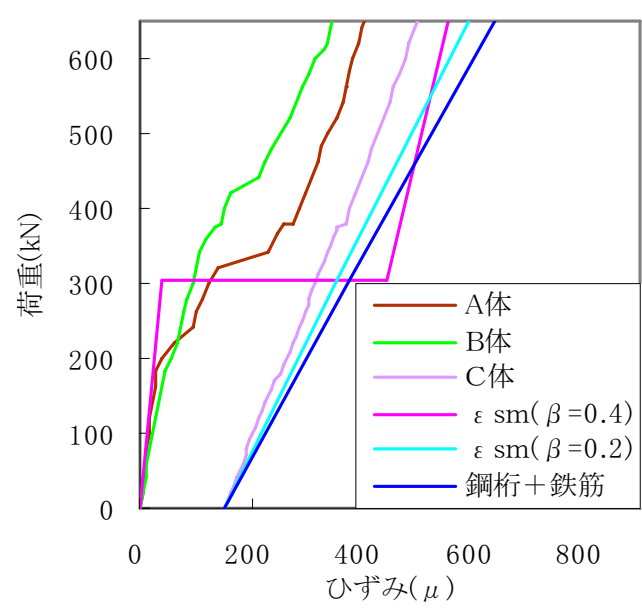

図-21 断面 a における下鉄筋のひずみ

定常ひび割れ開始時の鋼桁＋鉄筋の平均ひずみ $\varepsilon_{2}$

$$
\varepsilon_{2}=\frac{M_{s t}}{E_{s} I_{1}} Z_{1}+\varepsilon_{s h}
$$

\section{(2) 考察}

図-21，図-22より，A 体，B 体は，断面 a の方が断 面 bよりも, ひずみの急変の発生が早く, ひずみの大 きさも, 荷重 $400 \mathrm{kN}$ 以降の B 体を除けば大きい傾向に あることがわかる、これは，桁中央の曲げモーメント が一番大きく, 桁端に向かって小さくなるためであり, 図-4〜図-6からわかるように，ひび割れが析中央付近 から発生しているためと思われる。また，A 体，B 体 では，ひずみの急変が認められるが，C体では，ひずみ の急変は認められない.これは, 図-4～図-6からわか るように, A 体, B 体は, 荷重が $600 \mathrm{kN}$ 以下で, コン

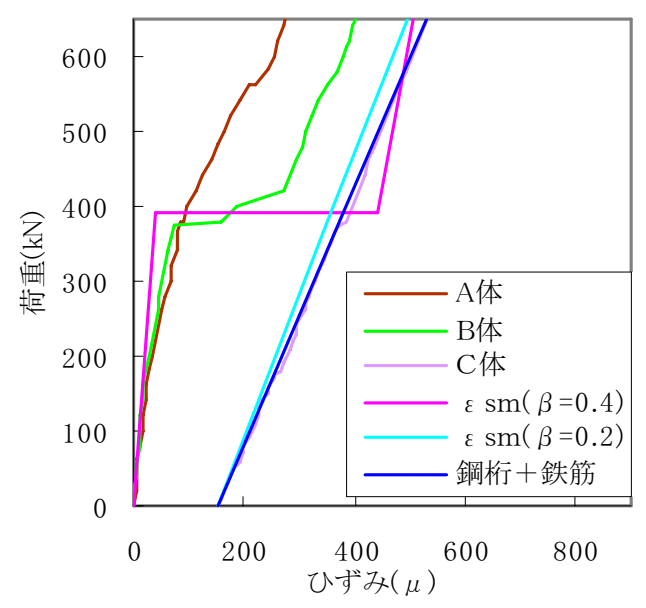

図-22 断面 b における下鉄筋のひずみ

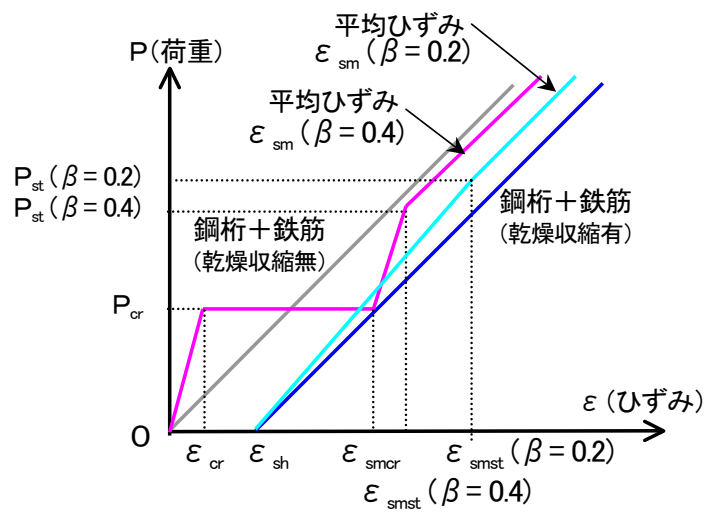

図-23 鉄筋のひずみ理論線概略図

クリート床版に，新たにひび割れが発生しているが，C 体は，荷重が $600 \mathrm{kN}$ 以下で，新たなひび割れの発生が 
ないためと思われる，C 体は，断面 $\mathrm{a} ， \mathrm{~b}$ ともに，傾き の変化点は認められない，また，A体，B 体に比心゙, 最 初から荷重一ひずみ曲線の傾きが小さいことがわかる. これは，図-6からわかるように，疲労試験中に，ひび 割れが出揃ってしまい, ひび割れ発生により剛性が低 下したためと思われる。.さらに，A体，B 体のひずみの 急変は, 初期疲労荷重以上の, 荷重 $200 \sim 400 \mathrm{kN}$ 付近 で起こっていることから, 中間支点付近の鉄筋とコン クリートとの付着は, 初期疲労荷重載荷では切れない が，定常疲労荷重を載荷すると切れると思われる。ま た，鉄筋とコンクリートとの付着が切れるのは，中間 支点付近が最も早いと思われ，付着が切れた後の力の やりとりは, 中間支点付近以外の, まだ付着の切れて いない鉄筋とコンクリートによって行われていると思 われる。これらのことから，鉄筋とコンクリートとの 付着が切れるのは, 定常疲労レベルの荷重を載荷した 場合であり, 初期疲労レベルの荷重載荷では，曲げモー メントが最大となる中間支点付近でさえ, テンション スティフニング効果はあると思われる。初期疲労レベ ル（荷重 $200 \mathrm{kN})$ は, 通常の走行時の荷重状態であり, 定常疲労レベル（荷重 $600 \mathrm{kN}$ ) は, 設計荷重状態であ る. よって, 通常の走行時を想定した場合, 最も条件の 厳しい中間支点部近傍（今回の実験では 200 600 mm) でさえ, テンションスティフニング効果を期待するこ とができ，したがって，桁全長にわたってテンションス ティフニング効果を期待することができると思われる.

ひずみの大きさは，断面 $\mathrm{a}, \mathrm{b}$ ともに， A 体， B 体は， 初期ひび割れ発生荷重以下において, $\beta=0.4$ の $\varepsilon_{s m}$ と $\beta=0.2$ の $\varepsilon_{s m}$ の間に位置している. 特に, 荷重が $200 \mathrm{kN}$ 以下において, $\beta=0.4$ の $\varepsilon_{s m}$ とおよそ一致している. ま た, $\mathrm{C}$ 体は, 荷重 $600 \mathrm{kN}$ 以下において, $\beta=0.2$ の $\varepsilon_{s m}$ とおよそ一致している. よって, 初期疲労レベルのひず みは, $\beta=0.4$ 程度の $\varepsilon_{s m}$ により求めることができ, 初 期疲労レベルから定常疲労レベルのひずみは, $\beta=0.2$ $\sim 0.4$ の $\beta$ を用いた $\varepsilon_{s m}$ により求めることができると思 われる。

\section{7. 鋼上フランジの荷重一ひずみの関係}

\section{(1) 計測結果}

鋼上フランジのひずみの，上面から見た計測位置を 図-18に，床版断面図を図-19に示す，静的載荷試験に おける鋼上フランジの荷重一ひずみの関係について，荷 重 $600 \mathrm{kN}$ 以下の様子を, 中心から $200 \mathrm{~mm}$ 離れた断面 $\mathrm{a}$ について図-24に, 中心から $600 \mathrm{~mm}$ 離れた断面 $\mathrm{b}$ に ついて図-25に，鋼フランジのひずみ理論線概略図を 図-26に示す。

$\varepsilon_{\text {smst }}$ は, Hanswille の理論に基づく平均ひずみの計
表-7 鋼上フランジの定常ひび割れ開始時のひずみ

\begin{tabular}{c|c|c}
\hline$\beta$ & 0.4 & 0.2 \\
\hline 平均ひずみ $(\mu \mathrm{m})$ & 289 & 381 \\
\hline 鋼桁十鉄筋断面のひずみ $(\mu \mathrm{m})$ & 371 & 421 \\
\hline
\end{tabular}

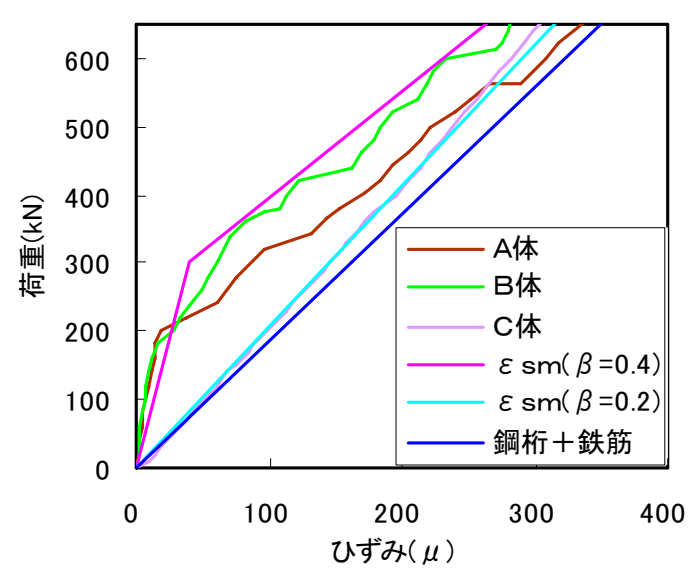

図-24 断面 a における鋼上フランジのひずみ

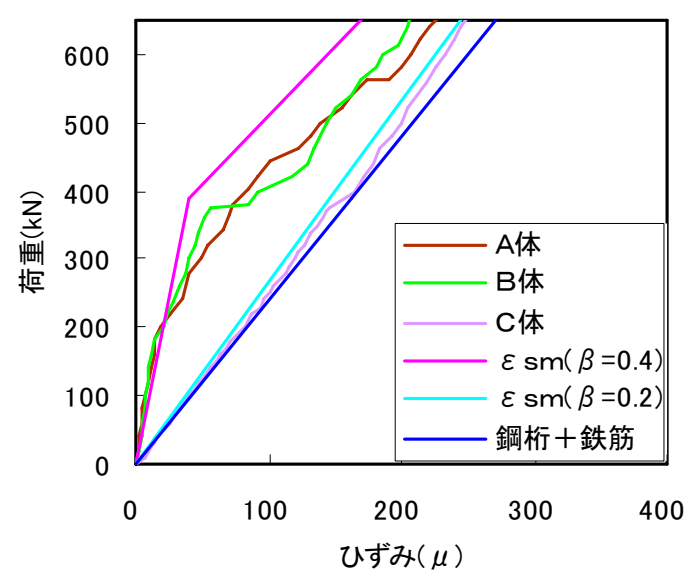

図-25 断面 $\mathrm{b}$ における鋼上フランジのひずみ

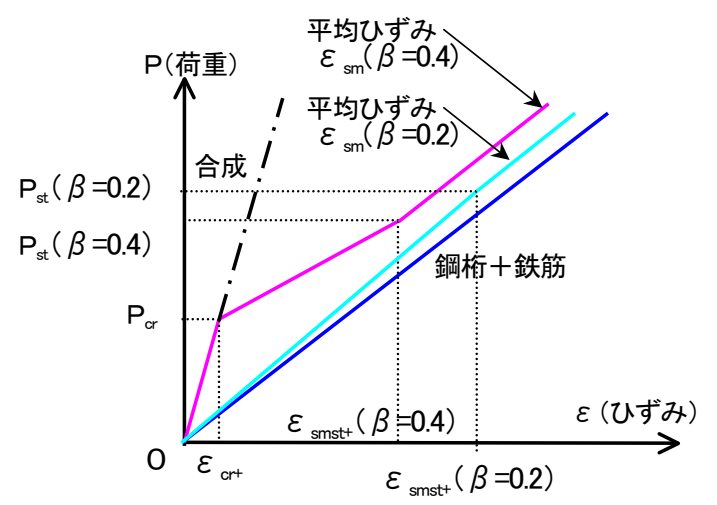

図-26 鋼フランジのひずみ理論線概略図

算式から算出した值であり，図-26のように仮定した。 断面 $\mathrm{a}, \mathrm{b}$ の各ひずみの值は, 図-18に示す左右 1)～3） 
の平均值である．なお，鋼上フランジは乾燥収縮の影 響は考慮していない，定常ひび割れ開始時のひずみを 表-7に示す．計算式は次のとおりである.

【鋼上フランジのひずみ】

$\varepsilon_{c r+}$ は，式(18)のひび割れ発生直前ひずみ $\varepsilon_{c r}$ を鋼上 フランジの位置まで平面保持の仮定を用い算出した值 である. ‘鉄筋十鋼析”においても， $\varepsilon_{c r+}$ 同様，式 (21) の定常ひび割れ開始時の鋼桁十鉄筋断面のひずみ $\varepsilon_{2}$ を 上フランジの位置まで平面保持の仮定を用い算出した 值である.

ひび割れ発生時の平均ひずみ $\varepsilon_{c r+}$

$$
\varepsilon_{c r+}=\frac{Z_{0}-h_{c} / 2}{Z_{0}} \varepsilon_{c r}
$$

定常ひび割れ開始時の平均ひずみ $\varepsilon_{\text {smst }}+$

$\varepsilon_{s m s t+}=\frac{M_{s t}}{E_{s} \cdot I_{1}}\left(Z_{1}-\frac{h_{c}}{2}\right)-\frac{\Delta N_{s}}{E_{s} \cdot A_{g}}-\frac{\Delta N_{s} \cdot Z_{g}}{E_{s} \cdot I_{g}}\left(Z_{g}-\frac{h_{c}}{2}\right)$

定常ひび割れ開始時の鋼桁十鉄筋断面のひずみ $\varepsilon_{2+}$

$$
\varepsilon_{2+}=\frac{Z_{1}-h_{c} / 2}{Z_{1}}\left(\varepsilon_{2}-\varepsilon_{s h}\right)
$$

\section{(2) 考察}

図-24，図-25より，A 体，B 体，C体ともに，おお よそ，床版の下鉄筋と同様の傾向を示していることが

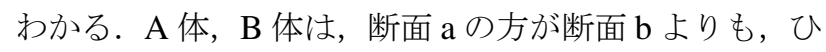
ずみの急変が早く, ひずみの大きさも大きい傾向にあ る.これは, 下鉄筋と同様, 桁中央の曲げモーメント が一番大きく, 桁端に向かって小さくなるためであり, 図-4〜図-6からわかるように，ひび割れが枌中央付近 から発生しているためと思われる。 また，A 体，B体 では，ひずみの急変が認められるが， C 体では，ひず みの急変は認められない。これも，図-4～図-6からわ かるように，A 体， B 体は，荷重が $600 \mathrm{kN}$ 以下で，コ ンクリート床版に, 新たにひび割れが発生しているが, $\mathrm{C}$ 体は, 荷重が $600 \mathrm{kN}$ 以下で, 新たなひび割れの発生 がないためと思われる。 A 体，B 体は，断面 aにおいて は, 傾きの変化点の荷重值は, 理論線とは違うものの, ひび割れ発生前および後における傾きはおよそ一致し ている．また，断面 $\mathrm{b}$ においては，傾きの変化点の荷 重値は, 理論線とおよそ一致しており,ひび割れ発生前 および後における傾きもおよそ一致している。C体は, 断面 $\mathrm{a}, \mathrm{b}$ ともに, 傾きの変化点は認められない. また, $\mathrm{A}$ 体， $\mathrm{B}$ 体に比べ，最初から荷重一ひずみ曲線の傾きが 小さいことがわかる。これも，下鉄筋と同様，図-6か らわかるように, 疲労試験中に, ひび割れが出揃ってし まい，ひび割れ発生により剛性が低下したためと思わ れる.さらに，下鉄筋と同様， $\mathrm{A}$ 体，B 体のひずみの急 変は, 初期疲労荷重以上の, 荷重 $200 \sim 400 \mathrm{kN}$ 付近で 起こっていることから, 中間支点付近の鋼上フランジ
とコンクリートとの付着は, 初期疲労荷重載荷では切 れないが，定常疲労荷重を載荷すると切れると思われ る.また, 鋼上フランジとコンクリートとの付着が切 れるのは, 中間支点付近が最も早いと思われ, 付着が 切れた後の力のやりとりは, 中間支点付近以外の, ま だ付着の切れていない鋼上フランジとコンクリートに よって行われていると思われる。これらのことから, 鋼 上フランジとコンクリートとの付着が切れるのは, 定 常疲労レベルの荷重を載荷した場合であり, 初期疲労 レベルの荷重載荷では, 曲げモーメントが最大となる 中間支点付近でさえ, テンションスティフニング効果 はあると思われる，よって，下鉄筋と同様，通常の走行 時を想定した場合, 最も条件の厳しい中間支点部近傍 （今回の実験では 200～600 mm）でさえ，テンションス ティフニング効果を期待することができ，したがって， 桁全長にわたってテンションスティフニング効果を期 待することができると思われる.

ひずみの大きさは，断面 $\mathrm{a}, \mathrm{b}$ ともに， $\mathrm{A}$ 体， B 体は， 初期ひび割れ発生荷重以下において, $\beta=0.4$ の $\varepsilon_{s m}$ と $\beta=0.2$ の $\varepsilon_{s m}$ の間に位置している. 特に, 荷重が $200 \mathrm{kN}$ 以下において, $\beta=0.4$ の $\varepsilon_{s m}$ とよく一致している. ま た， $\mathrm{C}$ 体は，荷重 $600 \mathrm{kN}$ 以下において， $\beta=0.2$ の $\varepsilon_{s m}$ とおよそ一致している.よって, 初期疲労レベルのひず みは, $\beta=0.4$ 程度の $\varepsilon_{s m}$ により求めることができ, 初 期疲労レベルから定常疲労レベルのひずみは, $\beta=0.2$ $\sim 0.4$ の $\beta$ を用いた $\varepsilon_{s m}$ により求めることができると思 われる。

\section{8. まとめ}

本論文では，連続合成桁の負曲げ部分を再現した疲 労試験, および静的載荷実験によって, 中間支点部の 疲労挙動を把握することを目標とした。これらの検討 により, 以下の結論が得られた。

（1）負曲げを受ける中間支点部ではひび割れの影響 を受けるため, 定常ひび割れ荷重より小さい荷重 で，スタッド基部とコンクリートの付着切れが起 きる場合があり, 現状の耐力式でスタッドの耐力 を評価しても問題ないが，付着を期待することは できない。

（2）スタッド基部とコンクリートとの付着，床版の 下鉄筋とコンクリートとの付着, および鋼上フラ ンジとコンクリートとの付着は, 初期疲労試験で は切れていないと推察でき, 初期疲労レベルでは, 疲労試験後も, テンションスティフニングの効果 は期待できる。

（3）中間支点部近傍（今回の実験では 200〜 600 mm) での下鉄筋，および鋼上フランジのひずみは，初 
期疲労レベルでは，式 (20) において $\beta=0.4$ とお いた $\varepsilon_{s m}$ により，初期疲労レベルから定常疲労レベ ルでは, $\beta=0.2 \sim 0.4$ の值を用いた $\varepsilon_{s m}$ により求め ることができる.

謝辞：本研究の一部は, 国土交通省からの委託を受け て実施した「鉄道技術基本整備のための調査研究」の 一環として行われたものである。本実験の供試体設計 に当たっては, (独) 鉄道建設・運輸施設整備支援機構の 鈴木喜弥氏・藤原良憲氏に有益な助言をいただきまし た。記して謝意を表します。

\section{参考文献}

1) 川田忠樹(監修), 野村國勝, 梶川靖治(編著): 複合構造 橋梁，技報堂出版，1994.

2) Hanswille, G.: Cracking of concrete mechanical models of the design rules in EUROCODE 4, Conf. Report, Composite Construction in Steel and Concrete III, ASCE, pp.420-433, 1993.

3) Roik, K., Hanswille, G. (著), 伊藤紘一, 平城弘一(訳) : 合成桁におけるひび割れ幅の制限, 橋梁と基礎, 93-2, pp.33-40, 1993.

4) 栗田章光, 大山理, マーカスルートナー：二重合成連 続箱析橋の現状と課題, 第 4 回鋼構造と橋に関するシン ポジウム論文報告集, 土木学会鋼構造委員会, pp.45-58, 2001.

5) 長井正嗣, 奥井義昭, 岩崎英治 : 連続合成桁の初期ひび 割れ状態を考慮したひび割れ幅，鉄筋応力算定法の一提 案，土木学会論文集，No.759/I-67，pp.283-292， 2004.

6) 谷口望, 依田照彦: 負曲げを受ける合成桁のひび割れに
関する研究，土木学会論文集，No.668/I-54，pp.243-257， 2001.

7) 安川義行, 稲葉尚文 : 連続合成 2 主桁橋の設計・施工, 第 4 回鋼構造と橋に関するシンポジウム論文報告集，土 木学会鋼構造委員会, pp.11-24, 2001.

8) (社) 日本橋梁建設協会 : PC 床版を有するプレストレス しない連続合成 2 主桁橋の設計例と解説， 2001.

9)（財）高速道路技術センター：PC 床版鋼連続合成 2 主桁 橋の設計・施工マニュアル, 2002.

10) 保坂鐵矢, 杉本一朗 : 鉄道における最近の鋼・コンクリー 卜複合橋梁, 橋梁と基礎, 2000-7, pp.31-40, 2000.

11) 長井正嗣, 家村剛: Hanswille 教授に聞く (インタビュー), 橋梁と基礎, Vol.34, No.11, pp.33-39, 2000.

12）富岡佐和子, 谷口望, 入部孝夫, 碇山晴久, 神谷崇, 依 田照彦：連続合成桁の中間支点部におけるズレ止めの疲 労挙動に関寸る実験的検討, 土木学会第 60 回年次学術 講演会, 2005.

13) 運輸省鉄道局 監修, (財) 鉄道総合技術研究所編: 鉄道構 造物等設計標準・同解説 鋼 - 合成構造物, 丸善, 2000 .

14）中本啓介, 長井正嗣, 奥井義昭, 岩崎英治, 細見雅生 : 負曲げを受ける合成桁のひび割れ挙動に関する実験的研 究, 構造工学論文集, Vol.49A, pp.1143-1152, 2003.

15) 谷口望, 池田学, 碇山晴久, 入部孝夫, 小野沢直, 依田 照彦: 負曲げを受ける鉄道用合成桁のひび割れに関する 実験的研究, 構造工学論文集, Vol.51A, pp.1459-1469, 2005.

16) 土木学会 : 複合構造物の性能照査指針(案), 構造工学シ リーズ 11, 2002.

17）富岡佐和子, 谷口望, 入部孝夫, 碇山晴久, 神谷崇, 依 田照彦: 連続合成桁の中間支点部におけるひび割れ幅算 定に関する検討（その $2:$ び割れ幅算定について），土 木学会第 61 回年次学術講演会, 2006.

\title{
EXPERIMENTAL STUDY ON A FATIGUE BEHAVIOR NEAR THE INTERMEDIATE SUPPORTS OF CONTINUOUS COMPOSITE GIRDERS WITH HEADED STUDS
}

\author{
Sawako TOMIOKA, Nozomu TANIGUCHI, Haruhisa IKARIYAMA and Teruhiko YODA
}

\begin{abstract}
This experimental research aims to examine a fatigue behavior of concrete slabs and headed studs in a continuous steelconcrete composite girder under negative bending. In particular, the fatigue behavior near the intermediate supports is fully investigated by using test specimens. It follows from the present experimental study that the bond between studs and concrete and the bond between flange plate and concrete become weak after the fatigue loading, and that the tension stiffening effects of the concrete slabs are expected except the intermediate support where the negative bending moment becomes largest.
\end{abstract}

